\title{
Assessing the impact of corporate entrepreneurship in the financial performance of subsidiaries of Colombian business groups: under environmental dynamism moderation
}

\section{Antonio Rodriguez-Peña ( $\boldsymbol{\sim}$ arodriguezp@universidadean.edu.co )}

\section{Research}

Keywords: Corporate entrepreneurship, entrepreneurial orientation, corporate venturing, environmental dynamism, business group, SmartPLS, emerging economies, emerging market firms, Colombia

Posted Date: February 1st, 2021

DOI: https://doi.org/10.21203/rs.3.rs-96202/v2

License: (c) (i) This work is licensed under a Creative Commons Attribution 4.0 International License.

Read Full License 


\section{Abstract}

Corporate entrepreneurship creates opportunities in employment, technological advances, value creation, and cultural transformation for entrepreneurial ecosystems, entrepreneurs, governments, economies and society around the globe. The purpose of this study is to assess the impact of corporate entrepreneurship on the financial performance of subsidiaries in Colombian business groups under the moderating effect of the environmental dynamism, because the relationship between corporate entrepreneurship and financial performance in emerging economies must differ from developed economies. Using a crosssectional Structural Equation Modeling analysis, this study assessed the impact of entrepreneurial orientation and corporate venturing on the firm financial performance of 87 subsidiaries of Colombian business groups at different levels of environmental dynamism. This study also confirms that the relationship between corporate entrepreneurship and performance is context-dependent, and that entrepreneurial orientation has a strong and positive causal relationship with corporate venturing. Additionally, subsidiaries of Colombian business groups increase their financial performance when also does the entrepreneurial orientation, and decrease financial performance when so does corporate venturing. Furthermore, the results show that environmental dynamism does not have a moderating effect on the relationship between corporate entrepreneurship of subsidiaries in Colombian business groups and their performance. This paper would contribute to important areas in Latin America business, where such studies are scarce.

\section{Introduction}

Nowadays, corporate entrepreneurship (CE) is an important trend to improve firm financial performance (FP) [Bouchard \& Fayolle, 2017; Ferreira et al., 2018; Ireland et al., 2009a; Siota \& Prats, 2020]. Previous studies have shown that iconic companies such as Google, 3M, Siemens, IBM, Intel, Motorola and Microsoft apply CE strategies (Covin \& Miles, 2007; Finkle, 2012; Fry, 1987; Schaeffer, 2015). This term refers to the entrepreneurial behavior of established companies (Kuratko, 2017), while corporate venturing (CV) and entrepreneurial orientation (EO) are domains of CE (Kuratko, 2017). CV refers to company efforts that lead to the creation of companies within the organization (Kuratko \& Audretsch, 2013), and EO reflects the processes that key decision-makers follow to define strategies for achieving organizational purposes, maintaining the vision and creating competitive advantages for the company (Rauch et al., 2009). Furthermore, environmental dynamism (ED) refers to the speed and the way in which the business environment changes (Lumpkin \& Dess, 2001).

Prior literature has revealed a positive causal relationship between CE and FP in developed economies (Bierwerth et al., 2015; Morris, Kuratko \& Covin, 2011; Wiklund \& Shepherd, 2003), and moderating effects of ED over the relationship between the above (Ambad \& Wahab, 2016; Lumpkin \& Dess, 2001). Besides, many studies have approached the effects of CE on FP in developed economies (Narayanan, Yang \& Zahra, 2009; Wiklund, 1999). However, little research to date has examined those effects in emerging economies (Demirkan, Yang \& Jiang, 2019; De Villiers-Scheepers, 2012), leaving a gap in the literature about CE in Latin America, where it is a recent trend (Kantis \& Angelelli, 2020; Prats \& Siota, 2018). This 
comes up with the question of whether these causal relations are similar for emerging economies, because their conditions are very different (Kelley, Singer \& Herrington, 2016).

Emerging economies have shortcomings such as a weak legal environment, a lack of financial resources, and a shortage of skilled labor, which hinders the development of companies (Zhou, Gao \& Zhao, 2017). Furthermore, the entrepreneurship ecosystems of developed and emerging economies have marked differences in many contexts: institutional environment, government support, technological advances, cultural influences, socioeconomic conditions, characteristics, motivations and ambitions of entrepreneurs (Carayannis et al., 2016; Farinha et al., 2018; Ferreira et al., 2018; Kelley et al., 2015b). Moreover, questions like how these differences affect $\mathrm{CE}$ activities in emerging economies remain unanswered (Demirkan et al., 2019).

The motivations for this research arise from several studies. Equipo UDD Ventures (2020) argued that CE creates opportunities in employment, technological advances, value creation and cultural transformation for Latin American ecosystems, entrepreneurs, governments, economies and society. Second, CE requires more research to assess how moderating factors affect its results (Kuratko, 2017; Narayanan et al., 2009; Rauch et al., 2009). Third, in the last seven years, corporate ventures have quadrupled worldwide, where the biggest companies have a higher adoption level than the smaller ones (Siota \& Prats, 2020); Latin America, for example, has an average adoption level of $16 \%$, far from $75 \%$ of Fortune 100 list (Knox, 2019; Siota \& Prats, 2020). Likewise, 70 \% of corporations are investing in CE (Prats \& Siota, 2018). Moreover, this study is the first of its kind to address these questions in the Colombian context.

Thus, the purpose of this study was to assess the impact of CE on FP of subsidiaries of Colombian business groups (SCBG) under the moderating effect of ED. To explore that, this work applied a mail survey with adapted scales, used in past researches, to employees of SCBG. Furthermore, it used structural equation modeling (SEM) to assess the relationships among the model variables. Finally, the present article studied the literature review and development of hypotheses based on a behavioral model of the relationship between $\mathrm{CE}$ and FP of SCBG, and the moderating effect of ED on this relationship. It also took into account the research method, results, discussion, managerial implications, limitations, future research directions, and, lastly, conclusions.

\section{Literature Review}

\subsection{Corporate Entrepreneurship}

This is a recent term that has attracted the attention of academics since the 70's (Kuratko, 2017). The proliferation of terms to refer to CE dispersed the attention of researchers and made it difficult to build and strengthen their theory (Ferreira, 2010; Hind \& Steyn, 2015; Sharma \& Chrisman, 1999).

CE encompasses two types of phenomena and the processes surrounding them (a) the birth of new business within an existing organization, i.e., internal innovation or venturing, and (b) the transformation 
of organizations through the renewal of the key ideas on which they are built, i.e., strategic renewal. (Guth \& Ginsberg, 1990, p. 5)

In the 70's, CE was a strategy for managing large organizations in dynamic markets, and the research focused on the creation of teams to cope entrepreneurial activities that generated growth in organizations (Kuratko, 2017). In the 80's, CE, understood as an innovation method, was prolific in research; conservative and entrepreneurial innovation models were compared, and CE was seen as an opportunity generator of large companies. Success factors for innovation were analyzed (Kuratko, 2017). In this decade, the first CE book was written (Pinchot, 1986) and the first investigations of the relationship between CE and FP began (Miller, Wilson \& Adams, 1988).

The 90's catapulted the research of CE. The principal subjects were the relationship between CE, FP, and ED (Vozikis et al., 1999): CE as an innovation mechanism to update organizations (Ferreira, 2001; Covin \& Miles, 1999), the relationship between CE and the firm policy (Barringer \& Bluedorn, 1999), the research of CE types (Covin \& Miles, 1999), and CE as a strategy to develop skills and knowledge (Floyd \& Wooldridge, 1999). "Knowledge is a fundamental building block of entrepreneurial ventures" (Carayannis \& Provance, 2018, p. 188). Starting in the 21st century, strategic entrepreneurship emerged as the third domain of CE; this was studied from the culture perspective (Garvin \& Levesque, 2006) and the Corporate Entrepreneurship Assessment Instrument (CEAl) emerged as a tool for measuring CE (Kuratko, Hornsby \& Covin, 2014).

However, several perspectives need research to understand the relationship between CE and FP. Some of them are the influence of mediating and moderating variables, the differences conditioned by characteristics of the natural business environment of each region and the magnitude of the relationship between CE and performance (Knight, 1997; Rauch et al., 2009; Thomas \& Mueller, 2000; Wiklund \& Shepherd, 2005). "There remains a greater need for further research about CE in organizational settings" (Kuratko, 2017, p. 442).

\subsection{Behavioral model of CE and FP}

Covin \& Slevin (1991) argued that entrepreneurship effectiveness is a phenomenon that depends on organizational routines and individual behaviors; this, having in mind that behavioral manifestations of entrepreneurship may be a measure of the firm's entrepreneurial level. Thus, an organization assumes an entrepreneurial posture if it visualizes the possibility of high returns. Moreover, it will develop high-risk projects, showing aggressive behavior in the search for opportunities, being proactive and taking the initiative in front of opportunities before its competitors (Miller, 2011). Recently, the literature shows that the research regarding the relationship between CE and FP is in the exploratory stage (Alam, Nasir, \& Rehman, 2020).

The overarching model of Figure 1 is represented by EO and CV as the independent variables, while FP reflected in return on equity (ROE) - and revenue growth (RG) are the dependent ones (Kreiser \& Davis, 2010; Zahra, 1993). 


\subsection{Entrepreneurial Orientation}

A firm with entrepreneurially-oriented stances has innovative, proactive, risk-taking, autonomous and competitive behaviors (Anderson et al.,2015; Lumpkin \& Dess, 2001; Miller, 2011). Furthermore, entrepreneurial firms are bold to introduce products and take part in high-risk projects with high-return possibilities, which require extensive amounts of resources to undertake in uncertain environments (De Clercq, Dimov \& Thongpapanl, 2013; Miller, 1983). Additionally, the literature shows a positive relationship between EO and company performance (Ambad \& Wahab, 2016; Anderson et al., 2015; Covin \& Slevin, 1991; Karacaoglu, Bayrakdaroglu, \& San, 2012; Kaya, 2006; Lee et al., 2019; Mohamad et al., 2011; Wiklund, 1999). However, how strong is the relationship between EO and FP remains an open question (Rauch et al., 2009).

Although some authors declared that in developed countries the entrepreneurially oriented behaviors of a company have a positive relationship with its profitability and growth (Covin, Green \& Slevin, 2006; Ireland et al., 2009; Lumpkin \& Dess, 1996), there are insufficient data to prove that this is true in emerging economies, specifically in SCBG. For these reasons, this paper proposes the next hypothesis.

Hypothesis 1. EO has a positive relation with CV in SCBG.

Hypothesis 2. EO has a positive relation with the FP of SCBG.

\subsection{Corporate Venturing}

The fundamental idea of $\mathrm{CV}$ is that a large firm, with the ambition to achieve financial objectives and strategies, cooperates with a small and autonomous unit to develop a business model (Hill et al., 2009; Sharma \& Chrisman, 1999). CV has a relation with the creation of new business units, product innovation $(\mathrm{Pl})$, the acquisition and sponsorship of new companies, and the degree to which companies strengthen in terms of the technologies they use (Zahra, 1993).

Although prior studies have related CV to the firm's growth and profitability (Ambad \& Wahab, 2016; Antoncic \& Hisrich, 2001), and some scholars have shown in developed countries that CV initiatives generate economic benefits for the company and improve its market performance (e.g. Antoncic \& Hisrich, 2001; Garud, Jain \& Kumaraswamy, 2002; Zahra, 1996), there is not enough data to prove that this is true in emerging economies, specifically in SCBG. On the other hand, CV projects require great resources and organizational capabilities (Wiklund, 1999; Tang et al., 2008); therefore, a company without enough resources and capabilities runs a high risk of failure if it tries to carry out CV projects that are out of its reach (Tang et al., 2008), which can negatively affect the company's performance. Additionally, many companies that use $\mathrm{CV}$ activities never achieve or support positive overall outcomes through their venturing efforts (Covin \& Miles, 2007). The above explained leads to the next hypothesis.

Hypothesis 3. CV has a negative relation with the FP of SCBG.

\subsection{Environmental Dynamism}


Previous scholars have established that ED is related to the business environment in an unpredictable form of change (Duncan, 1972; Lumpkin \& Dess, 2001; Tosi, Aldag \& Storey, 1973) and to the uncertainty that diminishes the manager's ability to predict events and their impact on the organization (Lumpkin \& Dess, 2001). Furthermore, ED is related to how quickly products become obsolete in an industry and how fast must be updated the technology used in an industry; how predictable are the reactions of competitors and how predictable are changes in tastes and consumer demands (Zahra, 1993).

The more dynamic and hostile environment, the higher the innovation is needed (Miller et al., 1988; Miller \& Friesen, 1982). Several studies in developed countries have emphasized ED has a moderating effect between CE and FP (Zahra \& Covin, 1995; Tajeddini \& Mueller, 2018). Wiklund \& Shepherd (2005), Zhang (2009), Frank, Kessler \& Fink (2010) and Kim \& Kim (2016) found no evidence of the moderating role of ED in the EO-FP relationship. Additionally, Zahra (1993) realized that the moderating effect of ED on the EO-FP relationship in static and impoverished environments is negative. Then, considering that researchers have not determined the effect of ED on the relationship between SCGB's CE and its performance to this date, this work proposes the next two additional hypotheses.

Hypothesis 4. The relationship between EO of SCBG and FP is moderated by ED. SCBG performance increases with EO but at a faster rate for those in dynamic environments.

Hypothesis 5. The relationship between CV of SCBG and FP is moderated by ED. SCBG performance increases with $\mathrm{CV}$ but at a faster rate for those in dynamic environments.

\subsection{Business groups in emerging economies}

A business group aims to take advantage of the market inefficiencies or the lack of regulatory authorities in emerging economies through the diversification gained with a network of firms. Scholars state that "a business group is a collection of legally independent firms that are linked by multiple ties, including ownership, economical means (such as inter-firm transactions), and social relations (family, kinship, friendship), through which they coordinate to achieve mutual objectives" (Khanna \& Rivkin, 2001; Yiu et al., 2007, p. 1553). Furthermore, considering that "business groups are significant engines of growth" (Stramaglia, 2010, p. 209), and that no research has examined CE in business groups in emerging economies (Wilches \& Rodríguez, 2016), the findings presented here provide insights to understand CE in this context.

\section{Methods}

This was a quantitative and cross-sectional research. The methodological design included two steps: first, a stage of adaptation and validation of scales to the context, to measure the exogenous variables of the model; and second, the estimation of the relations between the exogenous variables with the FP of SCBG. This, to test the five hypotheses assessed, the relationships between CE and FP, the effect of the moderating variable (ED) on the relationships between EO and CV with FP, and the interaction terms (IT), ED-EO and ED-CV. The target population was 857 from the biggest SCBG. The data collection procedure 
was carried out through a mail survey, for which the sampling frame was master's students and alumni of two private universities in Bogotá. This research worked with 87 SCBG, with the data of 202 employees selected by homogeneous convenience sampling from 700 survey responses (Jager, Putnick \& Bornstein, 2017). Table 1 shows respondent characteristics.

Table 1. Respondent characteristics

\begin{tabular}{lcc}
\hline Respondent profile & Number & Percentage \\
\hline Ages & 13 & $6 \%$ \\
Less than 25 & 62 & $31 \%$ \\
\hline Between 25 and 30 & 40 & $20 \%$ \\
\hline Between 30 and 35 & 37 & $18 \%$ \\
\hline Between 35 and 40 & 27 & $13 \%$ \\
\hline Between 40 and 45 & 12 & $6 \%$ \\
\hline Between 45 and 50 & 6 & $3 \%$ \\
\hline Between 50 and 55 & 3 & $1 \%$ \\
\hline Between 55 and 60 & 2 & $1 \%$ \\
\hline More than 60 & 202 & \\
\hline Gender & 8 & $4 \%$ \\
\hline Female & 194 & $96 \%$ \\
\hline Male & 202 & \\
\hline Study level & 100 & $50 \%$ \\
\hline Specialization & 56 & $28 \%$ \\
\hline Professional & 40 & $20 \%$ \\
\hline Master's degree & 2 & $1 \%$ \\
\hline PhD candidate & 2 & $1 \%$ \\
\hline Doctor & 2 & $1 \%$ \\
\hline Other & 202 & \\
\hline Job title & 79 & $39 \%$ \\
\hline Professional analyst & 55 & $27 \%$ \\
\hline Director / coordinator / area manager & 22 & $11 \%$ \\
\hline Project manager & 9 & $4 \%$ \\
\hline Department manager & 3 & $1 \%$ \\
\hline Vice-president & 34 & $17 \%$ \\
\hline Other & & \\
\hline & & \\
\hline & & \\
\hline
\end{tabular}

Source: computed by the author

The 7-point Likert-type semantic differential scales to measure exogenous variables -such as EO, CV and ED- were taken from seminal literature and adapted to the Colombian context (Covin \& Slevin, 1989; Lumpkin \& Dess, 2001; Miller \& Friesen, 1982; Zahra, 1993); and also was the financial data -to measure the endogenous variable were ROE- and RG, using equations (1) and (2) [Kreiser \& Davis, 2010]. These were drawn from the Emerging Markets Information Service (EMIS) database, recognized worldwide as the leading provider of data for emerging economies. Considering that each company belongs to a specific industry, it was necessary to standardize these data using equations (3) and (4) [Zahra, 1993].

$R O E=$ net income $/$ total equity

Eq. (1)

$R G=$ (current year's revenue - last year's revenue) / (last year's revenue)

Eq. (2)

$R O E N i=\left(R O E_{-} C i-A R O E_{-} s\right) /\left(\sigma\left(R O E_{-} s\right)\right)$ 
Where:

ROEN $_{i} \quad$ Normalized ROE of the company $\mathrm{i}$

$R O E_{-C i} \quad$ ROE of the company $\mathrm{i}$

$A R O E_{-} S \quad$ Average ROE of the sector

ROE_S ROE of the sector

$\sigma \quad$ Standard deviation

$R G N_{i} \quad$ Normalized RG of the company $\mathrm{i}$

$R G_{-C i} \quad$ Net RG of the company $\mathrm{i}$

$A R G \_$Average RG of the sector

RG_S Net RG of the sector

This study applied Partial Least Squares-Structural Equation Modeling (PLS-SEM) using SmartPLS 3 software, this one combines factorial and regression analysis, allowing simultaneous examination of relationships between observable and latent variables and measurement valuation, as well as between latent variables and structural model assessment. PLS-SEM aims to maximize the explained variance $\left(R^{2}\right)$ of the latent endogenous variables of the SEM model. Considering the practical rules of $R^{2}$ analysis, the results of $0.75,0.50$ or 0.25 for endogenous constructs are substantial, moderate or weak. According to Falk \& Miller (1992), the minimum value for $\mathrm{R}^{2}$ should be 0.10 . PLS-SEM has advantages when sample sizes are small and the model has many indicators and relationships, like in this research (Hair et al., 2018; Hair et al., 2017). Besides, PLS-SEM is better to evaluate convergence (Gefen, Rigdon \& Straub, 2011); furthermore, it has an outstanding ability to explain and predict endogenous latent variables, proceeding from the model estimates on the coefficient of determination $\mathrm{R}^{2}$ (Ringle, Sarstedt \& Straub, 2012).

The sample size recommendation in PLS-SEM for a statistical power of $80 \%$ is a coefficient of determination $\left(R^{2}\right)$ of 0.2 , a significance level of $5 \%$ and a model complexity level of three is 75 firms (Cohen, 1992; Hair et al., 2017; Marcoulides \& Saunders, 2006). On the other hand, according to the "10times rule" method, the minimum sample size must be 10 times the maximum number of inner or outer links pointing to any of the latent variables of the model (Kock \& Hadaya, 2018). There must be considered that, in the model used in this research, the maximum number of links pointing at the dependent variable is 3 , which multiplied by 10 equals 30 . Despite that, the sample size was 87 firms. To 
test the validity and reliability of the structural and measurement models, the techniques listed in Table 2 were applied.

Table 2. Measurement and structural model validation

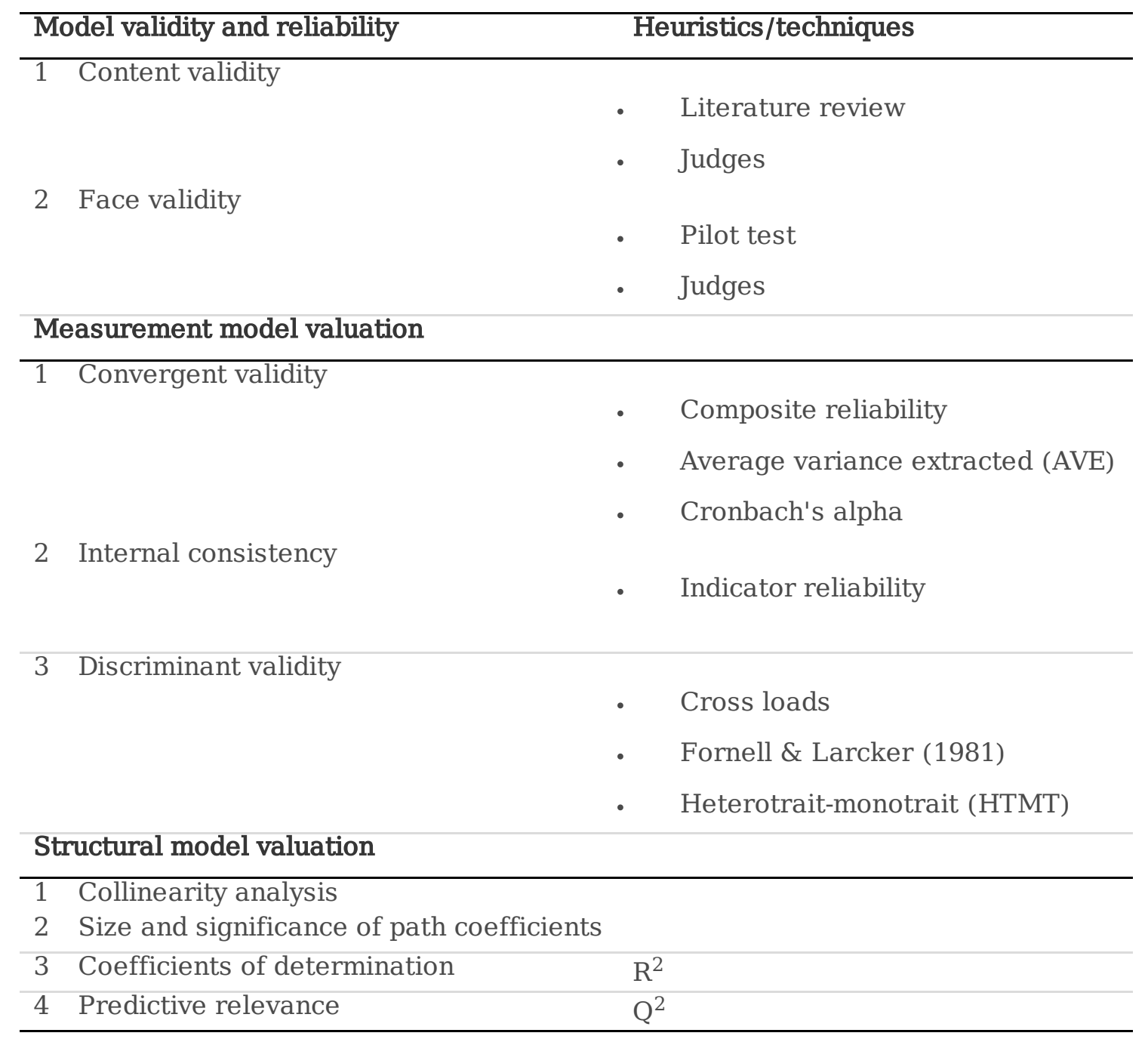

Note. Adapted from (Hair J. , Hult, Ringle, \& Sarstedt, 2017)

\section{Results}

This research aimed to assess the relationship between EO and CV, the impact of EO and CV on the FP of SCBG under the moderating effect of ED, and the moderating effect of ED on the relationship of CE and FP of SCBG. Table 3 provides descriptive statistics and the correlation matrix for all variables. The correlation between the independent variables was relatively high. Additionally, ED has a positive correlation with the variables technological entrepreneurship (TE) and expansion and growth (EG); and RG has a negative correlation with $\mathrm{PI}$.

Table 3. Descriptive statistics and correlations 


\begin{tabular}{|c|c|c|c|c|c|c|c|c|c|c|c|c|c|c|}
\hline & Mean & S.D. ${ }^{b}$ & $\mathrm{ED}$ & IN & PR & RT & $\overline{\mathrm{AU}}$ & $\overline{A G}$ & $\mathrm{BC}$ & $\overline{\mathrm{PI}}$ & $\mathrm{TE}$ & $\mathrm{EG}$ & $\mathrm{ROE}$ & $\mathrm{RG}$ \\
\hline $\mathrm{ED}^{\mathrm{a}}$ & 3.65 & 1.26 & 1 & & & & & & & & & & & \\
\hline IN & 4.21 & 1.39 & .194 & 1 & & & & & & & & & & \\
\hline PR & 4.67 & 1.46 & .104 & $.605^{* *}$ & 1 & & & & & & & & & \\
\hline RT & 3.98 & 1.47 & .168 & $.561^{* *}$ & $.604^{* *}$ & 1 & & & & & & & & \\
\hline $\mathrm{AU}$ & 4.84 & 1.16 & .020 & $.429^{* *}$ & $.556^{* *}$ & $.625^{* *}$ & 1 & & & & & & & \\
\hline $\mathrm{AG}$ & 4.45 & 1.20 & .007 & $.384^{* *}$ & $.417^{* *}$ & $.461^{* *}$ & $.394^{* *}$ & 1 & & & & & & \\
\hline $\mathrm{BC}$ & 4.51 & 1.32 & .052 & $.631^{* *}$ & $.570^{* *}$ & $.571^{* *}$ & $.474^{* *}$ & $.600^{* *}$ & 1 & & & & & \\
\hline PI & 4.65 & 1.27 & .153 & $.655^{* *}$ & $.549^{* *}$ & $.590^{* *}$ & $.412^{* *}$ & $.404^{* *}$ & $.734^{* *}$ & 1 & & & & \\
\hline $\mathrm{TE}$ & 3.97 & 1.50 & $.244^{*}$ & $.514^{* *}$ & $.541^{* *}$ & $.572^{* *}$ & $.445^{* *}$ & $.253^{*}$ & $.303^{* *}$ & $.519^{* *}$ & 1 & & & \\
\hline EG & 4.00 & 1.49 & $.288^{* *}$ & $.624^{* *}$ & $.521^{* *}$ & $.556^{* *}$ & $.395^{* *}$ & $.279^{* *}$ & $.433^{* *}$ & $.574^{* *}$ & $.609^{* *}$ & 1 & & \\
\hline ROE & -0.09 & 1.16 & -.191 & -.047 & .048 & -.107 & .119 & -.075 & -.046 & -.141 & -.140 & -.143 & 1 & \\
\hline RG & 0.00 & 1.05 & -.208 & -.089 & -.028 & .021 & .144 & -.127 & -.092 & $-.253^{*}$ & .021 & .029 & .169 & 1 \\
\hline
\end{tabular}

Note $^{a}$. The first column includes principal latent variables that are used in this study: environmental dynamism (ED); innovativeness (IN); proactiveness (PR); risk-taking (RT); autonomy (AU); aggressiveness (AG); business creation (BC); product innovation (PI); technological entrepreneurship (TE); expansion and growth (EG); return on equity (ROE); revenue growth (RG).

Note ${ }^{b}$. Standard deviation.

*. The correlation is significant at the 0.05 level (bilateral).

**. The correlation is significant at the 0.01 level (bilateral).

$\mathrm{n}=87$

Source: computed by the author using SPSS

\subsection{Measurement instrument validation}

The first thing to do is to examine the measurement model, which includes internal consistency and convergent and discriminant validity; the objective is to ensure that the measures used in the analysis are reliable and valid. Then, the structural model can be examined. The analysis demonstrates that the research model has internal consistency and convergent and discriminant validity, as seen in the measurement model valuation in Table 4, the structural model valuation in Table 7, the cross-loadings criterion and the confidence intervals bias-corrected of HTMT that support the discriminant validity of the model (Hair et al., 2017; Henseler et al., 2015).

\section{Assessing reflective measurement model}

The indicator loadings above 0.708 show that the construct explains over $50 \%$ of the indicator's variance, providing acceptable item reliability (Hair et al., 2018). The composite reliability between 0.70 and 0.90 shows that the model has "satisfactory to good" internal consistency reliability (Hair et al., 2018). To test convergent validity, AVE values were calculated, which were well above 0.5. Therefore, all reflective constructs present high levels in terms of convergent validity (Hair et al., 2018).

Table 4. Measurement model valuation 


\begin{tabular}{|c|c|c|c|c|c|c|c|}
\hline \multirow{3}{*}{$\begin{array}{l}\text { Latent } \\
\text { variable }\end{array}$} & \multirow[t]{3}{*}{ Indicators } & \multicolumn{2}{|c|}{ Convergent validity } & \multicolumn{3}{|c|}{ Internal consistency reliability } & \multirow[t]{2}{*}{ Discriminant validity } \\
\hline & & Loadings & $\begin{array}{l}\text { Indicator } \\
\text { reliability }\end{array}$ & $\mathrm{AVE}^{\mathrm{C}}$ & $\begin{array}{l}\text { Composite } \\
\text { reliability }\end{array}$ & $\begin{array}{c}\text { Cronbach's } \\
\text { alpha }\end{array}$ & \\
\hline & & $>0.70$ & $>0.50$ & $>0.50$ & $0.60-0.90$ & $0.60-0.90$ & $\begin{array}{c}\text { HTMT }^{\mathrm{d}} \text { confidence interval does } \\
\text { not include } 1\end{array}$ \\
\hline \multirow[t]{2}{*}{$\mathrm{AG}^{\mathrm{a}}$} & $\mathrm{AG} 1 \mathrm{~b}$ & 0.939 & 0.882 & 0.7838 & 0.8784 & 0.7381 & Yes \\
\hline & AG2 & 0.828 & 0.686 & & & & \\
\hline \multirow[t]{3}{*}{ RT } & RT1 & 0.900 & 0.810 & 0.8111 & 0.9280 & 0.8836 & Yes \\
\hline & RT2 & 0.913 & 0.834 & & & & \\
\hline & RT3 & 0.889 & 0.790 & & & & \\
\hline \multirow[t]{4}{*}{ IN } & IN1a & 0.857 & 0.734 & 0.7055 & 0.9052 & 0.8595 & Yes \\
\hline & IN1b & 0.877 & 0.769 & & & & \\
\hline & IN2a & 0.871 & 0.759 & & & & \\
\hline & IN2b & 0.749 & 0.561 & & & & \\
\hline \multirow[t]{4}{*}{$\mathrm{AU}$} & AU1 & 0.843 & 0.711 & 0.6505 & 0.8814 & 0.8206 & Yes \\
\hline & AU2 & 0.808 & 0.653 & & & & \\
\hline & AU4 & 0.757 & 0.573 & & & & \\
\hline & AU6 & 0.816 & 0.666 & & & & \\
\hline \multirow[t]{4}{*}{$P R$} & PR1a & 0.890 & 0.792 & 0.7894 & 0.9374 & 0.9107 & Yes \\
\hline & PR1b & 0.923 & 0.852 & & & & \\
\hline & PR1c & 0.847 & 0.717 & & & & \\
\hline & PR2a & 0.891 & 0.794 & & & & \\
\hline \multirow[t]{5}{*}{$\mathrm{BC}$} & $\mathrm{BC} 2$ & 0.811 & 0.658 & 0.6334 & 0.8959 & 0.8543 & Yes \\
\hline & BC3 & 0.818 & 0.669 & & & & \\
\hline & BC4 & 0.702 & 0.493 & & & & \\
\hline & BC5 & 0.829 & 0.687 & & & & \\
\hline & BC6 & 0.812 & 0.659 & & & & \\
\hline \multirow[t]{2}{*}{$\mathrm{TE}$} & TE3 & 0.773 & 0.598 & 0.7024 & 0.8243 & 0.5875 & No \\
\hline & TE5 & 0.898 & 0.806 & & & & \\
\hline \multirow[t]{4}{*}{ EG } & EG1 & 0.853 & 0.728 & 0.6806 & 0.8949 & 0.8434 & Yes \\
\hline & EG2 & 0.830 & 0.689 & & & & \\
\hline & EG3 & 0.830 & 0.689 & & & & \\
\hline & EG5 & 0.785 & 0.616 & & & & \\
\hline \multirow[t]{4}{*}{ PI } & PI1 & 0.722 & 0.521 & 0.6845 & 0.8962 & 0.8442 & Yes \\
\hline & PI2 & 0.850 & 0.723 & & & & \\
\hline & PI3 & 0.879 & 0.773 & & & & \\
\hline & PI5 & 0.849 & 0.721 & & & & \\
\hline \multirow[t]{3}{*}{ ED } & ED2 & 0.834 & 0.696 & 0.6179 & 0.8288 & 0.6971 & Yes \\
\hline & ED3 & 0.761 & 0.579 & & & & \\
\hline & ED4 & 0.762 & 0.581 & & & & \\
\hline \multirow[t]{2}{*}{ FP } & RGN & 0.746 & 0.557 & 0.5843 & 0.7375 & 0.2890 & Yes \\
\hline & ROEN & 0.782 & 0.612 & & & & \\
\hline
\end{tabular}

Note $^{a}$. The first column includes principal latent variables that are used in this study: aggressiveness (AG); risk-

taking (RT); innovativeness (IN); autonomy (AU); proactiveness (PR); business creation (BC); technological entrepreneurship (TE); expansion and growth (EG); product innovation (PI); environmental dynamism (ED); financial performance (FP); revenue growth normalized (RGN); return on equity normalized (ROEN).

Note ${ }^{b}$. The names of the items correspond to the way they are labeled on their measurement scales.

Note ${ }^{C}$. AVE: average variance extracted.

Note $^{d}$. HTMT: heterotrait-monotrait.

Adapted from (Hair et al., 2017).

Source: computed by the author using SmartPLS 3 
To assess discriminant validity, "which is the extent to which a construct is empirically distinct from other constructs in the structural model" (Hair et al., 2018, p. 1), the Fornell \& Larcker (1981) criterion were calculated. If the square root of the AVE of each reflective construct (shown in the diagonal on Table 5) is higher than the correlations possessed by the rest of the constructs in the model, then constructs have discriminant validity. These results show that all the constructs are valid measures and unique concepts.

Table 5. Discriminant validity - Fornell-Larcker criterion

\begin{tabular}{|c|c|c|c|c|c|c|c|c|c|c|c|}
\hline & $\overline{\mathrm{AU}}$ & $\mathrm{AG}$ & $\overline{B C}$ & ED & EG & FP & IN & PR & $\mathrm{PI}$ & RT & TE \\
\hline $\mathrm{AU}^{\mathrm{a}}$ & $0.8065^{b}$ & & & & & & & & & & \\
\hline AG & 0.4286 & 0.8853 & & & & & & & & & \\
\hline BC & 0.4706 & 0.6281 & 0.7959 & & & & & & & & \\
\hline ED & 0.0171 & 0.0287 & 0.0564 & 0.7861 & & & & & & & \\
\hline EG & 0.4025 & 0.3236 & 0.4381 & 0.2773 & 0.8250 & & & & & & \\
\hline FP & 0.1718 & -0.1143 & -0.0893 & -0.2635 & -0.0788 & 0.7644 & & & & & \\
\hline IN & 0.4268 & 0.4137 & 0.6334 & 0.1916 & 0.6242 & -0.0895 & 0.8399 & & & & \\
\hline PR & 0.5569 & 0.4367 & 0.5773 & 0.0968 & 0.5208 & 0.0155 & 0.6068 & 0.8885 & & & \\
\hline PI & 0.4067 & 0.4246 & 0.7385 & 0.1700 & 0.5931 & -0.2634 & 0.6593 & 0.5557 & 0.8273 & & \\
\hline RT & 0.6279 & 0.4828 & 0.5729 & 0.1700 & 0.5656 & -0.0609 & 0.5605 & 0.6056 & 0.5886 & 0.9006 & \\
\hline TE & 0.4836 & 0.3017 & 0.3411 & 0.2549 & 0.6206 & -0.0819 & 0.5381 & 0.5729 & 0.5437 & 0.5872 & 0.8381 \\
\hline \multicolumn{12}{|c|}{$\begin{array}{l}\text { Note }^{a} \text {. The first column includes principal latent variables that are used in this study: } \\
\text { autonomy (AU); aggressiveness (AG); business creation (BC); environmental dynamism (ED); expansion and growth (EG); } \\
\text { financial performance (FP); innovativeness (IN); proactiveness (PR); product innovation (PI); risk-taking (RT); technological } \\
\text { entrepreneurship (TE). } \\
\text { Note }^{b} \text {. Diagonals (bold) represent the square root of the AVE, while other entries represent the correlations. }\end{array}$} \\
\hline
\end{tabular}

Source: computed by the author using SmartPLS 3

Although in research the Fornell \& Larcker (1981) and cross-loads criterion are very used, they are not reliable to measure discriminant validity with absolute certainty (Hair et al., 2017). Thus, the HTMT criterion proposed by Henseler et al. (2015) must be a better one. HTMT is the ratio of the correlations between traits and the correlations among traits; it is also an estimation of what the actual relationship would be between two constructs if they were perfectly measured; in other words, if they were utterly reliable (Hair et al., 2017). Table 6 presents the HTMT ratio values among the exogenous model constructs. Keeping in mind that Henseler et al. (2015) recommended a maximum threshold of 0.85 for HTMT results, and considering that, out of the 55 findings from Table 6, only two present values are exceeding 0.85 , there is enough evidence to suggest that the model has discriminant validity.

The "bootstrapping" technique was applied to test if HTMT is different from 1, which consists of randomly taking a series of sub-samples, replacing the original data with the one estimated by the model 
and ultimately determining a confidence interval from the "bootstrap". This confidence interval is where the actual HTMT value lies, assuming a confidence level of $95 \%$; if the confidence interval does not contain the value 1 , then the compared constructs are empirically distinct and, therefore, show evidence of discriminant validity.

Table 6. Discriminant validity - HTMT ratio

$\begin{array}{llllllllll}\text { AU } & \text { AG } & \text { BC } & \text { ED } & \text { EG } & \text { FP } & \text { IN } & \text { PR } & \text { PI } & \text { RT }\end{array}$

\begin{tabular}{|c|c|c|c|c|c|c|c|c|c|c|}
\hline$\overline{\mathrm{AU}}$ & & & & & & & & & & \\
\hline AG & 0.4952 & & & & & & & & & \\
\hline $\mathrm{BC}$ & 0.5550 & 0.7567 & & & & & & & & \\
\hline ED & 0.1605 & 0.1234 & 0.1451 & & & & & & & \\
\hline EG & 0.4768 & 0.3565 & 0.5064 & 0.3929 & & & & & & \\
\hline FP & 0.3690 & 0.2962 & 0.2515 & 0.5717 & 0.2482 & & & & & \\
\hline IN & 0.5023 & 0.4824 & 0.7369 & 0.2671 & 0.7252 & 0.2622 & & & & \\
\hline PR & 0.6346 & 0.5081 & 0.6498 & 0.1687 & 0.5925 & 0.1886 & 0.6864 & & & \\
\hline PI & 0.4834 & 0.5079 & $0.8675^{b}$ & 0.2594 & 0.6933 & 0.5255 & 0.7780 & 0.6315 & & \\
\hline $\mathrm{RT}$ & 0.7329 & 0.5712 & 0.6587 & 0.2323 & 0.6461 & 0.1923 & 0.6437 & 0.6715 & 0.6758 & \\
\hline $\mathrm{TE}$ & 0.6733 & 0.3922 & 0.4394 & 0.3876 & 0.8683 & 0.3140 & 0.7370 & 0.7445 & 0.7448 & 0.7971 \\
\hline
\end{tabular}

Note ${ }^{a}$. The first column includes principal latent variables that are used in this

study: autonomy (AU); aggressiveness (AG); business creation (BC); environmental dynamism (ED); expansion and growth (EG); financial performance (FP); innovativeness (IN); proactiveness (PR); product innovation (PI); risk-taking (RT); technological entrepreneurship (TE).

Note ${ }^{b}$. HTMT values $>0.85$ are in boldface.

Source: computed by the author using SmartPLS 3

\section{Assessing structural model}

The research model displays no collinearity issues among predictor constructs, because variance inflation factor (VIF) values are below the threshold of 5 , as shown in the structural model valuation in Table 7 (Hair et al., 2017)

Table 7. Structural model valuation

\begin{tabular}{lccccc}
\hline & Path coefficients & t-value $^{\mathrm{b}}$ & $\begin{array}{c}95 \% \\
\text { confidence intervals }\end{array}$ & Significant & VIF $^{\mathrm{c}}$ \\
\hline EO --> FP a & 0.3699 & $2.087^{* *}$ & {$[-0.0015,0.6873]$} & No & 3.0350 \\
CV --> FP & -0.4232 & $2.454^{* *}$ & {$[-0.7454,-0.0643]$} & Yes & 3.1189 \\
\hline ED --> FP & -0.2242 & $1.961^{* *}$ & {$[-0.4009,0.1838]$} & No & 1.0518
\end{tabular}

Note $^{a}$. Entrepreneurial orientation (EO); corporate venturing (CV); environmental dynamism (ED); financial performance (FP)

Note ${ }^{b} \cdot{ }^{*} p<0.10 * * p<0.05 * * * p<0.01$

Note ${ }^{C}$. VIF: variance inflation factor

Two-tailed test $t$ value $=1.96$

VIF threshold value $=5$ 
Source: computed by the author using SmartPLS 3

Considering that collinearity is not a problem, the next step is to examine the $\mathrm{R}^{2}$ value of the endogenous construct. PLS-SEM aims to maximize the explained variance $\left(R^{2}\right)$ of the latent endogenous variables of the model. Considering the practical rules of $\mathrm{R}^{2}$-analysis, the results of $0.75,0.50$ or 0.25 for endogenous constructs are substantial, moderate or weak (Hair et al., 2018; Henseler et al., 2009). Then, the $\mathrm{R}^{2}$ of FP is weak (0.1277); however, according to Falk \& Miller (1992), the minimum value for $\mathrm{R}^{2}$ should be 0.10 .

To assess the PLS path model's predictive accuracy, the $Q^{2}$ value were calculated (Geisser, 1974; Stone M., 1974). As suggested by Hair et al. (2017), a model has predictive relevance if $Q^{2}$ is greater than 0 ; then, the results of $Q^{2}$ demonstrate that all exogenous variables have satisfactory predictive relevance, as shown in the PLS path model's predictive accuracy in Table 8 (Hair et al., 2017; Henseler et al., 2009).

Table 8. PLS path model's predictive accuracy

\begin{tabular}{|c|c|c|c|}
\hline Exogenous construct & $\mathrm{SSO}^{\mathrm{b}}$ & $\mathrm{SSE}^{\mathrm{C}}$ & $\mathrm{Qu}(=1-\mathrm{SSE} / \mathrm{SSO})^{\mathrm{d}}$ \\
\hline $\mathrm{AU}^{\mathrm{a}}$ & 3480000 & 2226190 & 0.3603 \\
\hline AG & 1740000 & 1265015 & 0.2730 \\
\hline $\mathrm{CV}$ & 1305000 & 1305000 & \\
\hline $\mathrm{BC}$ & 4350000 & 2610852 & 0.3998 \\
\hline $\mathrm{EO}$ & 1479000 & 1479000 & \\
\hline ED & 2610000 & 2610000 & \\
\hline EG & 3480000 & 2083007 & 0.4014 \\
\hline IN & 3480000 & 2064864 & 0.4066 \\
\hline PR & 3480000 & 1598949 & 0.5405 \\
\hline PI & 3480000 & 1628330 & 0.5321 \\
\hline RT & 2610000 & 1207631 & 0.5373 \\
\hline $\mathrm{TE}$ & 1740000 & 1217996 & 0.3000 \\
\hline \multicolumn{4}{|c|}{$\begin{array}{l}\text { Note }{ }^{a} \text {. The first column includes principal latent variables that are used in this study: autonomy (AU); aggressiveness (AG); } \\
\text { corporate venturing (CV); business creation (BC); entrepreneurial orientation (EO); environmental dynamism (ED); expansion } \\
\text { and growth (EG); innovativeness (IN); proactiveness (PR); product innovation (PI); risk-taking (RT); technological } \\
\text { entrepreneurship (TE). } \\
\text { Note }{ }^{b} \text {. SSO: sum of the squared observations. }\end{array}$} \\
\hline \multicolumn{4}{|c|}{ Note ${ }^{C}$. SSE: sum of the squared prediction errors. } \\
\hline Note ${ }^{d} \cdot \mathrm{Q}^{2}>0$ exogenous & ive relevano & nous ones. & \\
\hline
\end{tabular}

Source: computed by the author using Smart PLS 3

\subsection{Relation between EO and CV of SCBG}

As shown in the hypothesis testing in Table 9 and the SEM in Figure 2, EO and CV of SCBG have a strong positive causal relation $(B=.822, p=.000$ ), which provides support for hypothesis 1 . This keeps in line with earlier research that showed that EO reflects behaviors of the key decision-makers in front of the business context (Barringer \& Bluedorn, 1999; Covin \& Slevin, 1989), and that CV represents the 
manifestations of EO, such as innovative processes and products, and business units creation (Sharma \& Chrisman, 1999).

Table 9. Hypothesis testing

\begin{tabular}{|c|c|c|c|c|c|c|c|}
\hline Hypothesis & Relation & Standard Beta & t-value & $f^{2}$ & $q^{2}$ & $95 \%$ confidence intervals & Supported \\
\hline H1 & EO ----------> CV & $0.8222^{* * *}$ & 2.471 & 2.0670 & 0.038 & {$[0.739,0.871]$} & Yes \\
\hline $\mathrm{H} 2$ & EO --------> FP & $0.3699 * *$ & 2.048 & 0.0630 & -0.363 & {$[-0.029,0.686]$} & No \\
\hline H3 & CV ------> (-) FP & $-0.4232 * *$ & 2.440 & 0.0050 & 0.055 & {$[-0.757,-0.073]$} & Yes \\
\hline $\mathrm{H} 4$ & IT(ED-EO) --> FP & -0.0185 & 0.164 & 0.0005 & 0.010 & {$[-0.221,0.210]$} & No \\
\hline H5 & IT(ED-CV) --> FP & 0.0558 & 0.522 & 0.0029 & -0.007 & {$[-0.142,0.288]$} & No \\
\hline \multicolumn{8}{|c|}{ Note. $* * \mathrm{p}<0.05 * * * \mathrm{p}<0.01$} \\
\hline \multicolumn{8}{|c|}{ Note. Two-tailet test $t$ value $=1.96$} \\
\hline \multicolumn{8}{|c|}{ Note. $f^{2}$ range values: .02 small, .15 medium, .35 large } \\
\hline \multicolumn{8}{|c|}{ Note. $q^{2}$ range values: .02 small, .15 medium, .35 large } \\
\hline
\end{tabular}

Source: computed by the author using Smart PLS 3

\subsection{Effect of EO on the FP of SCBG under the moderating effect of ED}

As shown in the hypothesis testing in Table 9 and the SEM in Figure 2, although EO is positively related to firm performance $(B=.369, p=.037)$, this relationship could not be proven because the confidence interval contains $0[-0.029,0.686]$. Thus, hypothesis 2 did not find support. Although this result differs from those that proved the positive impact of EO on firm performance (Covin et al., 2006; Ireland et al., 2009; Tajeddini \& Mueller, 2018), it was coherent with others who could not prove this relationship either (Covin, Slevin, \& Schultz, 1994; George, Wood, \& Khan, 2001).

\subsection{Effect of CV on the FP of SCBG under the moderating effect of ED}

As shown in the hypothesis testing in Table 9 and the SEM in Figure 2, CV and FP of SCBG have a strong negative causal relation ( $\beta=-.423, p=.014$ ), which provides support for hypothesis 3 . This result coincides with Covin \& Miles (2007), who stated that many companies that apply CV strategies never achieve nor sustain positive results through these entrepreneurial projects. Furthermore, this result is consistent with Zahra \& Covin (1995), who expressed that many of the financial and market benefits take time to materialize; therefore, these benefits may not be clear (Narayanan et al., 2009).

\subsection{Moderation effect of ED between the relation of EO and FP of SCBG}

As shown in the hypothesis testing in Table 9 and the SEM in Figure 2, the IT, ED-EO, is not related to the firm performance of SCBG ( $\beta=-.018, p=.867)$. Thus, hypothesis 4 did not find support. This result is consistent with Kim \& Kim (2016), whose "[...] results showed that ED had no significant effect on the EOFP relationship ( $\beta=0.206$, n.s.)" (p. 7). It is also consistent with Zhang (2009), who found out that ED does not have a moderating effect on the relationship between EO of 143 subsidiaries of multinationals in China and their performance. On the other hand, the results of this research reaffirm those of Frank et al. 
(2010) and Wiklund \& Shepherd (2005b), who stated that the moderating effect of ED of the relationship between EO-FP is not significant.

Additionally, the effect size $\left(f^{2}\right)$ of the IT, ED-EO, is marginal $\left(f^{2}=0.0005\right)$ [Cohen, 1988]. Besides, as shown in the moderating effect of ED on EO and FP relationship in Figure 3, a higher EO raises the FP of SCBG. The results of the model with the moderating variable, ED, and without it (not reported for space limitations) were similar.

\subsection{Moderation effect of ED between the relation of CV and FP of SCBG}

As shown in the hypothesis testing in Table 9 and the SEM in Figure 5, the IT, ED-CV, is not related to firm performance of SCBG ( $\beta=.055, p=.610)$. Thus, hypothesis 5 did not find support. This result was contrary to Zahra \& Covin (1995) and Narayanan et al. (2009), who found the moderating effect of ED over the relationship between CV and FP. Furthermore, the effect size $\left(f^{2}\right)$ of the IT, ED-CV, is marginal ( $f^{2}$ $=0.0029$ ) [Cohen, 1988], as seen in the hypothesis testing in Table 9. Figure 4 shows an opposite relationship between CV and FP of SCBG.

In summary, this research found support for hypotheses 1 and 3 . However, it did not find support for hypotheses 2, 4 and 5, as shown in the hypothesis testing in Table 9. Therefore, the structural equation analysis revealed that EO has a strong and positive causal relationship with CV in this SCBC sample, and that CV has a negative impact on the FP of SCBG in the short term. Additionally, it could not be proven whether EO affects the FP of the SCBG, and whether ED moderates the relation between EO and CV with the FP of SCBG. The results of the model with and without the moderating variable, ED, were similar.

\section{Discussion}

The primary aim of this paper was to assess the impact of CE in the FP of SCBG under the moderation of ED. To fulfill this overarching goal, the analysis focused on answering five fundamental questions. The first one, "is there a positive causal relationship between EO and CV efforts in SCBG?". This research revealed that $\mathrm{EO}$ has a strong and positive causal relationship to $\mathrm{CV}$ in this sample, which concurs with earlier research that showed that EO corresponds to behaviors of the key decision-makers in the company in front of the business context (Barringer \& Bluedorn, 1999; Covin \& Slevin, 1989), and that CV explains the manifestations of EO, such as innovative processes, innovative products and business units creation (Sharma \& Chrisman, 1999).

Thus, this results suggest that $E O$ is the driving force of $C E$ and $C V$ projects rise if the firms have a strong EO (Covin \& Slevin, 1991; Kuratko, 2017). On the other hand, it suggests that the willingness to be innovative, proactive, competitive, autonomous and risk-taking oriented in the SCBG has a positive relationship with the development of products and firms consolidation; this is in line with Dess \& Lumpkin (2005), who stated that "firms often rely on an EO to enhance their corporate venturing activities" (p. 148). Also, this result not only highlights the importance of encouraging EO and CE strategies within the firm to generate companies based on knowledge and innovation (Campbell \& Carayannis, 2016), but also implies 
to count on enough resources and capabilities within the company as well as a stronger entrepreneurial and innovation ecosystems (Carayannis et al., 2018), which is coherent with the organizational models for CV activities revealed in Battistini, Hacklin \& Baschera (2013).

The second question, "is there a positive causal relationship between EO and the FP of SCBG?". Although the results meet significance, and meet algebraic sign criteria, the confidence interval based on the "bootstrap" presents problems that don't allow to support this relationship. Even when this result differs from those that proved the positive impact of EO on firm performance (Covin et al., 2006; Ireland et al., 2009; Tajeddini \& Mueller, 2018), this difference could be due to the fact that the last ones did not report confidence intervals. "Reporting of the bootstrapping confidence interval is less common despite their value-added but is likely to increase in the future" (Hair et al., 2017, p. 197). Moreover, this difference could be explained because the Colombian context is very different from the developed countries ones; then, like Rauch et al. (2009) found in their meta-analysis, this suggests that the EO-FP relationship varies depending on the context and contingencies (e.g. firm size, industry, and environment) (Lumpkin \& Dess, 2001; Zahra, 1993; Zahra \& Covin, 1995). At last, this result is coherent with others that could not prove this relationship either (Covin et al., 1994; George et al., 2001).

Moreover, this result suggests that CE has boundary conditions associated with the context of each country (Demirkan et al., 2019; Liu \& Vrontis, 2017; Miller, 2011). There must be considered that the impact of CE in the FP depends on economic drivers, such as gross domestic product, investment-grade sovereign rating, political and regulatory stability, and environmental hostility (Rauch et al., 2009; Sakhdari \& Farsi, 2016); then these differences between emerging and developed economies could explain these results. Whereas the dominant reason for wealth generation in emerging economies is the production intensity, based on efficiency and low costs by scale economies, in developed economies the dominant reason for wealth generation is through the creation of unique goods and services with significant innovations (Kelley t al., 2016; Farinha et al., 2018). The developed economies encourage the birth of knowledge-intensive companies and CE because of government support for entrepreneurship, entrepreneurial financing and training in BC.

Third, "is there a negative causal relationship between CV and FP of SCBG?". The result confirms the hypothesis that CV has a negative impact on the FP of SCBG's in the short term (Figure 4). This result suggests that considering that CV is a recent trend in Latin America (Prats \& Siota, 2018; Kantis, 2018; Kantis \& Angelelli, 2020), Colombian companies have not yet developed enough resources and organizational capabilities that allow them to impact their innovation systems with CV projects in a way that improves the FP. The first CV approximations in Colombia were Waira Colombia (https://hispam.wayra.com/colombia), since 2012; Ventures EPM (epm.com.co/site), since 2013; and Sura Ventures (groupsura.com), since 2016 (Kantis \& Angelelli, 2020).

Furthermore, according to Narayanan et al. (2009), some CV programs have strategic objectives, while others pursue financial goals. Then, these results suggest that the Colombian CV projects could be oriented to strategic benefits like learning and developing skills, international integration of the company's 
operations, refining response capacity, establishing better technological and management standards, inspiring internal creation of ideas and incorporating external knowledge (Battistini et al., 2013; Birkinshaw, 1997); these may take time to be reflected in the financial data (Zahra \& Covin, 1995). On the other hand, the present results are aligned with Covin \& Miles (2007), who stated that many companies that apply CV projects never achieve nor sustain positive results through these projects. Even more, this result is consistent with Zahra \& Covin (1995), who stated that many of the financial and market benefits take time to materialize; therefore, these benefits may not be clear (Narayanan et al., 2009).

In the fourth place, "does ED moderate the relationship between EO and the FP of SCBG?". This research could not prove that the impact of EO on performance increases as ED becomes more dynamic. These results are in line with Wiklund \& Shepherd (2005), Zhang (2009), Frank, Kessler \& Fink (2010) and Kim \& Kim (2016) who found no evidence of the moderating role of ED in the EO-FP relationship. Further, although the results are not significant, they suggest that the relationship between EO and FP is the same for different levels of ED (Figure 3). One explanation could be that ED in the Colombian context is so low that any increase fails to have an impact on the EO-FP relationship. This could be because Colombian economy is driven by efficiency and low production costs, as a result of scale economies (Kelley et al., 2016); then, the speed at which the products and services of Colombian industry become obsolete is very low, as these are products with low added value content, or plain commodities, such as coffee. Additionally, the Colombian condition of an economy based on efficiency makes it relatively easy to predict the competition strategies and the consumers' demands and tastes, making ED very low. Another reason could be that the relationship between EO and FP depends on the business group's ED and not on the specific industry of each firm.

Fifth and last, "does ED moderate the relationship between CV and the FP of SCBG?". Contrary to the results of Zahra \& Covin (1995), who found that CV efforts are context-specific, highlighting the moderating effect of ED over the relationship between CV and FP (Narayanan et al., 2009), this research is in line with Frank et al. (2010) and Kim \& Kim (2016) who also found no evidence that ED moderates the relationship between $\mathrm{CV}$ and FP.

In summary, this research suggests that there are differences between the impact of CE in emerging economies such as the Colombian one and those from developed economies. Additionally, this research proposes that this may be related to the marked differences between these two types of economies, while the Colombian economy is based on efficiencies and economies of scale of basic products, without much added value; on the other hand, developed countries support their economies on products unique and innovative, knowledge-based, who are generally pioneers in their field. It also suggests that the above influences the level of ED in a country like Colombia, where it can be very low if viewed from the perspective of product types, if they are basic products, their obsolescence speed is slow and the strategies of the competitors can be quite predictable, as well as customer tastes. Additionally, these results invite researchers to deepen their knowledge about the mechanisms and conditions required to improve the impact of CE on the innovation systems of organizations. 


\section{Managerial Implications}

From a practical perspective, the results contain important insights for managers and consultants of competitiveness, business strategy, open innovation and CE interested in understanding and improving the business group performance in emerging economies. This research confirms the existence of interrelationships between EO, CV and FP. However, the results suggest that business managers should considerate that, to successfully carry out $\mathrm{CV}$ initiatives that impact positively the FP of companies, high levels of EO are necessary, as well as the development of resources and capabilities that allow ensuring the success of CV projects. This is because CE is a new trend in Colombia and Latin America; then, the firms need to develop the resources and capabilities related to CV mechanisms. In addition, from the organizational structure perspective, companies need to develop capabilities to create better management plans for their innovation talent; for example, a new career development path for innovative employees. Additionally, from the perspective of innovation processes, companies need to improve their skills to create "minimum viable products" that allow them to go to market, controlling risks and skills to audit innovation processes, as well as to create effective innovation teams.

About CV mechanisms, the main ones are acquisitions, corporate venture capital, corporate accelerators and incubators, strategic alliances, venture builder, venture client, scouting missions, hackathons, innovation challenges or contests, and shared resources (Ortega \& Rotondo, 2020). About the organizational structure, most organizations usually only have two paths for career development for their employees, such as the technical route and the managerial route. An important competence for strengthening $\mathrm{CV}$ is the ability to develop a third path for those employees who wish to direct their career along the $\mathrm{CE}$ and innovation line.

From the analysis of the results, it could be inferred that ED, as understood in this research, when associated with the speed of obsolescence of the products, the ease of predicting the movements of the competition and the tastes of the consumers, is very low in Colombia. This is because the majority of Colombian products are basic, without added value; and, in some cases, they are commodities. This condition of ED means that its increases are not yet enough to improve the CE-FP relationship. The foregoing suggests the following implications for public policy makers at the national level, leaders of industrial associations, universities and business managers in Colombia.

The determinants of public policy are called to strengthen the innovation ecosystem in Colombia, encouraging the development of innovation and entrepreneurship skills from the early stages of citizen training. Additionally, the development of products with greater technological and knowledge-intensive content should be encouraged, which can lead to an increase in companies ED; for example, with tax strategies and investment in research and development, in a way that CV projects can influence positively the FP of the organizations.

The leaders of industrial associations and universities, as part of the country's innovation ecosystem, should be the first to come up with efforts to find fields of technological development, which involve the creation of products with high added value, knowledge-intensive, that help reduce the development gap 
between emerging economy countries, such as Colombia, and developed countries. The above would contribute to a greater alignment between CV projects and their positive impact on the EO-FP and CV-FP relationship.

Regarding company managers, the research leads to think that they should move towards new practices, such as open innovation and teamwork with startups; this, due to the advantages that these practices have. Among the advantages are a greater agility in the generation of new business ideas, the high motivation and willingness to risk that the members of a startup have, and the reduction of several limitations for innovation that already consolidated companies have.

This study revealed that the relationship between EO and FP of SCBG is the same for different levels of ED; then, in this context, it does not moderate this relationship. Thus, in the Colombian context, companies that belong to business groups do not perceive effects because of changes in ED, as measured by the research instrument. This may happen because of other factors, endogenous to the country, which considerably affect the company's performance, overshadowing the effect of ED.

Although all the exogenous factors that explain EO are relevant in SCBG, PR is the most important $\left(0.857^{\star \star *}\right)$, followed by RT $(0.839 * \star *)$, IN $\left(0.792^{\star \star *}\right)$, AU $\left(0.772^{\star \star *}\right)$ and AG $\left(0.625^{\star \star *}\right)$, as shown in the measurement model valuation in Table 4 and the results of the SEM in Figure 2. Likewise, with CV, all the explaining exogenous factors are relevant and significant; however, the managers of SCBS must consider that the most pertinent aspect at the time is the PI $\left(0.911^{\star \star \star}\right)$, followed by the CB $\left(0.834^{\star \star *}\right), E G\left(0.793^{\star \star \star}\right)$ and the least relevant is TE $(0.678 * \star *)$. Then, SCBG's managers must design strategies that allow improving TE, where the results show the greatest weakness, consistent with the dominant products, this is, commodities without added value.

The analysis of results can go down to the detail of each item, for example, PR1b has the greatest weight $\left(0.923^{\star \star *}\right)$ of PR. This item corresponds to the question "[when dealing with competitors, my company] rarely is the first company to introduce new products/services, administrative techniques, operation technologies. 1 <> 7 is sometimes the first company to introduce new products/services, administrative techniques, operation technologies?" (Lumpkin \& Dess, 2001, p. 442). Thus, the managers of SCBG should give priority to being the first companies to introduce new products/services, administrative techniques and operation technologies.

On the other hand, considering that the weights for the remaining items of PR $\left(0.8566^{\star \star *}\right)$ exceed 0.85 , and keeping up with their statements, then managers of SCBG may lend priority to being more competitive and staying ahead of their competitors by introducing new ideas and products. From a broader social perspective, an appropriate CE strategy could generate better conditions for employee development, because they are the central actors of innovation. Likewise, for the companies, CE is a competitive advantage that could improve employee retention, because people can perceive a working environment that values their innovation ideas.

\section{Limitations}


This study shows limitations that open opportunities for improvement in future research. The main limitations of this research are the quality and size of the sample and the access to financial information of the companies under study. The reliability of the estimated in the model depends on these factors.

Although the sample size exceeds the required for PLS-SEM, its achievement involved collecting 10 times the size of the sample used; from 700 surveys, only 87 met the inclusion criteria. However, this limitation was offset by the quality of the responses. This is based on the characteristics of the sample in terms of their level of training, the roles they play within the companies and the age distribution of the respondents. Regarding the training level, $100 \%$ are professionals, $50 \%$ have specialization training, $20 \%$ have master's degrees and even $1 \%$ have a doctorate degree. Also, $43 \%$ of those surveyed hold management roles, and $88 \%$ of the sample are between 25 and 50 years old (Table 1). The above generates confidence in the data, since these characteristics ensure that the respondents have criteria to evaluate the organizations where they work from different perspectives, lowering the bias that could be generated if the respondents were CEO's at the studied companies.

On the other hand, an important limitation for this research was the access to companies' financial information. The development of this research shows that in Colombia the access to financial information through data centers of a national order is extremely difficult; then, although the data was drawn from the EMIS database, recognized worldwide as the leading provider of data for emerging economies, the quality of data depends on this institution. In order to mitigate this limitation in future research, it is suggested that perception indexes of companies' financial indicators are included; these would be better for triangulating and complementing this information with primary data from the respondents.

\section{Future Research Directions}

This project allowed the identification of several lines of research that could allow the consolidation of a solid knowledge base to strengthen the development of CE and CV projects in Colombia. These lines of research are related to resources and capabilities necessary for CV projects, objectives of CV projects in Colombia, measurement of ED in the country, career development plans for innovative talent in companies, CV mechanisms more recommended for these last, comparison between the innovation ecosystems of emerging countries and developed countries, and the moderating effect of environmental hostility in the CE-FP relationship in Colombian industry. The following are some of the lines of research in which it is necessary to deepen to consolidate CE in Colombia:

- What are the resources and capabilities that companies in Colombia need to develop to improve results in CV projects?

- What kind of objectives do CV projects in Colombia have, strategic or financial? If they are strategic, what are they? (Learning and developing skills, international integration of the company's operations, refining response capacity, establishing better technological and management standards, inspiring internal creation of ideas, and incorporating external knowledge). 
- Considering that the results of this research suggest that the moderating effect of ED is not significant in Colombia because of the low ED, it is important to measure it.

- Having in mind that, from an organizational perspective, one of the suggested implications for company managers is the creation of career development plans for innovative talent within the company; this would facilitate open innovation processes and CV projects. In addition, it is important to investigate about of career development plans in outstanding companies in CE. Additionally, it is required an investigation of the career development plans of Latin American companies that are doing CV projects.

- In order to increase the impact of CV projects in Colombia, it is important to investigate which are the most recommended CV mechanisms for companies. The main ones are acquisitions, corporate venture capital, corporate accelerators and incubators, strategic alliances, venture builder, venture client, scouting missions, hackathons, innovation challenges or contests and shared resources (Ortega \& Rotondo, 2020).

- For CV projects, which are benchmark innovation ecosystems in developed countries, it is necessary to make a competitive comparison with the innovation ecosystem in Colombia.

- Impact of environmental hostility on the EO-FP relation in the Colombian industry.

\section{Conclusions}

To summarize, this article has directed greater attention to the impact of CE on the FP of SCBG under the moderating effect of ED in an emerging economy. The results show that the impact of CE on the FP of firms in emerging economies are different than what they appear to be in developed economies. In the same line, this study confirms that the relationship between CE and FP is context-dependent, and that EO has a strong and positive causal relationship to CV. Thus, the relationship between CE and FP in emerging economies differ from the one in developed economies, because of their divergences. The results also suggest that $\mathrm{EO}$ is the driving force of $\mathrm{CE}$, and the projects of $\mathrm{CV}$ are the results of $\mathrm{CE}$ efforts.

Additionally, the results show that ED does not have a moderating effect on the relationship between CE and the FP of SCBG. This is consistent with Kim \& Kim (2016), whose "results showed that ED had no significant effect on the EO-FP relationship" (p. 7). It is also consistent with Zhang (2009), who found out that ED does not have a moderating effect on the relationship between EO of 143 subsidiaries of multinationals in China and their FP. On the other hand, the results of this research coincide with those of Frank et al. (2010) and Wiklund \& Shepherd (2005b), who stated that the moderating effect of ED of the relationship between EO-FP is not significant.

Moreover, this result suggests that Colombian companies have not yet developed enough resources and organizational capabilities that allow them to impact their innovation systems with CV projects, in a way that improves the FP. It is possible that the Colombian CV projects are oriented to strategic benefits and not financial objectives. Furthermore, suggest that the moderating effect of the ED is insignificant in Colombia because the ED is very low. Finally, it is possible that this work represents a motivation for

Page 22/36 
future research that can lead to a greater understanding of how SCBG can guide their CE strategies to generate competitive advantages in the market.

\section{Abbreviations}

AG: aggressiveness; AU: autonomy; AVE: average variance extracted; BC: business creation; CE: corporate entrepreneurship; CEAl: Corporate Entrepreneurship Assessment Instrument; CV: corporate venturing; ED: environmental dynamism; EG: expansion and growth; EMIS: Emerging Markets Information Service; EO: entrepreneurial orientation; FP: financial performance; HTMT: heterotrait-monotrait; IN: innovativeness; IT: interaction term; PI: product innovation; PLS-SEM: Partial Least Squares-Structural Equation Modeling; PR: proactiveness; RG: revenue growth; ROE: return on equity; RT: risk-taking; SCBG: subsidiaries of Colombian business groups; SPSS: Statistical Package for the Social Sciences; TE: technological entrepreneurship; VIF: variance inflation factor.

\section{Declarations}

\section{Availability of data and material}

The dataset generated and analyzed during the current study are available in the DRIVE repository, [https://drive.google.com/file/d/10m3MVj-CxGNW_fQVeBQoneiqBk1X-lcz/view?usp=sharing].

\section{Competing interest}

The authors declare that they have no competing interests.

\section{Funding}

Not applicable.

\section{Authors' contributions}

AR: conceptualization, methodology, validation, formal analysis, investigation, writing - original draft and visualization. The author read and approved the final manuscript.

\section{Acknowledgements}

I want to thank the editor of the journal as well as the reviewers of my manuscript, whose accurate observations allowed me to give much more meaning to this research. Additionally, I thank each of the students and alumni who supported me and answered the survey.

\section{References}

Alam, M., Nasir, N. \& Rehman, C. Intrapreneurship concepts for engineers: a systematic review of the literature on its theoretical foundations and agenda for future research. Journal of Innovation and 
Entrepreneurship 9, 8 (2020). https://doi.org/10.1186/s13731-020-00119-3

Ambad, S., \& Wahab, K. (2016). The relationship between corporate entrepreneurship and firm performance: evidence from Malaysian large companies. International Journal of Business and Society, 17(2), 259-280. https://doi.org/10.33736/ijbs.524.2016.

Anderson, B., Kreiser, P., Kuratko, D., Hornsby, J., \& Eshima, Y. (2015). Reconceptualizing entrepreneurial orientation. Strategic Management Journal, 36(10), 1579-1596. https://doi.org/10.1002/smj.2298.

Antoncic, B., \& Hisrich, R. (2001). Intrapreneurship: construct refinement and cross-cultural validation. Journal of Business Venturing, 16(5), 495-527. https://doi.org/10.1016/S0883-9026(99)00054-3.

Barringer, B., \& Bluedorn, A. (1999). The relationship between corporate entrepreneurship and strategic management. Strategic Management Journal, 20(5), 421-444. https://doi.org/10.1002/(SICI)10970266(199905)20:5<421::AID-SMJ30>3.0.C0;2-0.

Battistini, B., Hacklin, F., \& Baschera, P. (2013). The state of corporate venturing: insights from a global study. Research-Technology Management, 56(1), 31-39. https://doi.org/10.5437/08956308X5601077.

Bierwerth, M., Schwens, C., Isidor, R., \& Kabst, R. (2015). Corporate entrepreneurship and performance: a meta-analysis. Small Business Economics, 45(2), 255-278. https://doi.org/10.1007/s11187-015-9629-1.

Birkinshaw, J. (1997). Entrepreneurship in multinational corporations: the characteristics of subsidiary initiatives. Strategic Management Journal, 18(3), 207-229.

Bouchard, V., \& Fayolle, A. (2017). Corporate entrepreneurship. London: Taylor and Francis. https://doi.org/10.4324/9781315747989.

Campbell, D.F.J., Carayannis, E.G. The academic firm: a new design and redesign proposition for entrepreneurship in innovation-driven knowledge economy. Journal of Innovation and Entrepreneurship 5, 12 (2016). https://doi.org/10.1186/s13731-016-0040-1

Carayannis, E. G., Dagnino, G. B., Alvarez, S., \& Faraci, R. (Eds.). (2018). Entrepreneurial ecosystems and the diffusion of startups. Edward Elgar Publishing. https://doi.org/10.4337/9781784710064

Carayannis, E. G., Ferreira, J. J., Ferreira, F. A. F., \& Peris-Ortiz, M. (2016). Location and Innovation Capacity in Multilevel Approaches: Editorial Note. Journal of the Knowledge Economy, 7(4), 837-841. https://doi.org/10.1007/s13132-015-0345-5

Carayannis, E. G., \& Provance, M. (2018). "Towards "skarse" entrepreneurial ecosystems: using agentbased simulation of entrepreneurship to reveal what makes regions tick". In Entrepreneurial Ecosystems and the Diffusion of Startups. Cheltenham, UK: Edward Elgar Publishing. doi: https://doi.org/10.4337/9781784710064.00013 
Cohen, J. (1992). A ower primer. Psychological Bulletin, 112(1), 155-159. doi: 10.1037//00332909.112.1.155.

Covin, J. G., \& Miles, M. P. (2006). Corporate Entrepreneurship and the pursuit of competitive advantage. Entrepreneurship Theory and Practice, 23(3), 47-63. https://doi.org/10.1177/104225879902300304.

Covin, J. G., Slevin, D. P., \& Schultz, R. L. (1994). Implementing strategic missions: effective strategic, structural and tactical choices. Journal of Management Studies, 31(4), 481-506.

https://doi.org/10.1111/j.1467-6486.1994.tb00627.x.

Covin, J., \& Miles, M. (1999). Corporate etrepreneurship and the pursuit of competitive advantage. Entrepreneurship Theory and Practice, 23(3), 47-63. https://doi.org/10.1177\%2F104225879902300304.

Covin, J., \& Miles, M. (2007). Strategic use of corporate venturing. Entrepreneurship Theory and Practice, 31(2), 183-207. https://doi.org/10.1111/j.1540-6520.2007.00169.x.

Covin, J., \& Slevin, D. (1989). Strategic management of small firms in hostile and benign environments. Strategic Management Journal, 10(1), 75-87. https://doi.org/10.1002/smj.4250100107.

Covin, J., \& Slevin, D. (1991). A conceptual model of entrepreneurship as firm behavior. Entrepreneurship Theory and Practice, 16(1), 7-25. https://doi.org/10.1177/104225879101600102.

Covin, J., Green, K., \& Slevin, D. (2006). Strategic process effects on the entrepreneurial orientation-sales growth rate relationship. Entrepreneurship Theory and Practice, 30(1), 57-81.

https://doi.org/10.1111/j.1540-6520.2006.00110.x.

De Clercq, D., Dimov, D., \& Thongpapanl, N. (2013). Organizational social capital, formalization, and internal knowledge sharing in entrepreneurial orientation formation. Entrepreneurship: Theory and Practice, 37(3), 505-537. https://doi.org/10.1111/etap.12021.

De Villiers-Scheepers, M. (2012). Antecedents of strategic corporate entrepreneurship. European Business Review, 24(5), 400-424. https://doi.org/10.1108/09555341211254508.

Demirkan, l., Yang, Q., \& Jiang, C. (2019). Corporate entrepreneurship of emerging market firms: current research and future directions. New England Journal of Entrepreneurship, 22(1), 5-30.

https://doi.org/10.1108/neje-04-2019-0024.

Dess, G., \& Lumpkin, G. (2005). The role of entrepreneurial orientation in stimulating effective corporate entrepreneurship. Academy of Management Perspectives, 19(1), 147-156.

https://doi.org/10.5465/ame.2005.15841975.

Duncan, R. (1972). Characteristics of organizational environments and perceived environmental uncertainty. Adm Sci Q, 17(3), 313-327. https://doi.org/10.2307/2392145. 
Equipo UDD Ventures. (2020). Corporate Venturing Latam Handbook: Guía para la colaboración entre corporaciones y startups. Retrieved from https://uddventures.udd.cl/blog/corporate-venturing-latamhandbook-gu\%C3\%ADa-para-la-colaboraci\%C3\%B3n-entre-corporaciones-y-startups

Falk, R., \& Miller, N. (1992). A primer for soft modeling. Akron, Ohio: The University of Akron Press.

Ferreira, J. J. (2001). Corporate entrepreneurship: A strategic and structural perspective. New England Journal of Entrepreneurship, 4(2), 59-70. https://doi.org/10.1108/NEJE-04-02-2001-B006

Ferreira, J. J. (2010). Corporate entrepreneurship and small firms growth. International Journal of Entrepreneurship and Small Business, 10(3), 24. https://doi.org/10.1504/IJESB.2010.033574

Farinha, L., Ferreira, J.J.M. and Nunes, S. (2018), Linking innovation and entrepreneurship to economic growth, Competitiveness Review, 28(4), pp. 451-475. https://doi.org/10.1108/CR-07-2016-0045

Ferreira, J. J., Carayannis, E. G., Campbell, D. F. J., Farinha, L., Smith, H. L., \& Bagchi-Sen, S. (2018). Geography \& Entrepreneurship: Managing Growth and Change. Journal of the Knowledge Economy, 9(2), 500-505. https://doi.org/10.1007/s13132-017-0514-9

Ferreira, J. J., Fernandes, C. I., \& Peris-Ortiz, M. (2018). How agents, resources and capabilities mediate the effect of corporate entrepreneurship on multinational firms' performance. European Journal of International Management, 12(3), 255-277. https://doi.org/10.1504/EJIM.2018.091369

Finkle, T. (2012). Corporate entrepreneurship and innovation in Silicon Valley: the case of Google, Inc. Entrepreneurship Theory and Practice, 36(4), 863-884. https://doi.org/10.1111/j.1540-6520.2010.00434.x.

Floyd, S., \& Wooldridge, B. (1999). Knowledge creation and social networks in corporate entrepreneurship: the renewal of organizational capability. Entrepreneurship Theory and Practice, 23(3), 123-144. https://doi.org/10.1177/104225879902300308.

Fornell, C., \& Larcker, D. (1981). Evaluating structural equation models with unobservable variables and measurement error. Journal of Marketing Research, 18(1), 39-50. https://doi.org/10.2307/3151312.

Frank, H., Kessler, A., \& Fink, M. (2010). Entrepreneurial orientation and business performance - a replication study. Schmalenbach Business Review, 62(2), 175- 198. DOI: 10.1007/BF03396804.

Fry, A. (1987). The Post-It-Note: an intrapreneurial success. SAM Advanced Management Journal, 36(4), 49.

Garud, R., Jain, S., \& Kumaraswamy, A. (2002). Institutional entrepreneurship in the sponsorship of common technological standards: the case of Sun Microsystems and Java. Academy of Management Journal, 45(1), 196-214. 
Garvin, D., \& Levesque, L. (2006). Meeting the challenge of corporate entrepreneurship. Harvard Business Review, 84(10), 102-112,150.

Gefen, D., Rigdon, E., \& Straub, D. (2011). An update and extension to SEM guidelines for administrative and social science research. MIS Quarterly: Management Information Systems, 35(2), iii-xiv. https://doi.org/10.2307/23044042.

George, G., Wood, J., \& Khan, R. (2001). Networking strategy of boards: implications for small and medium-sized enterprises. Entrepreneurship and Regional Development, 13(3), 269-285. https://doi.org/10.1080/08985620110058115.

Guth, W., \& Ginsberg, A. (1990). Guest editors' introduction: corporate entrepreneurship. Strategic Management Journal, 11, 5-15.

Hair, J. F., Hult, G. T., Ringle, C. M., \& Sarstedt, M. (2014). A primer on partial least squares structural equation modeling. Thousand Oaks.

Hair, J., Hult, G., Ringle, C., \& Sarstedt, M. (2017). A primer on partial least squares structural equation modeling (PLS-SEM) (2nd ed.). Los Angeles: Sage.

Hair, J., Risher, J., Sarstedt, M., \& Ringle, C. (2018). When to use and how to report the results of PLS-SEM. European Business Review, 31(1), 2-24. DOI: 10.1108/EBR-11-2018-0203.

Henseler, J., Ringle, C. M., \& Sinkovics, R. R. (2009). The use of partial least squares path modeling in international marketing. In R. R. Sinkovics, \& P. N. Ghauri, Advances in International Marketing (pp. 277319). Emerald Group Publishing Limited. https://doi.org/10.1108/S1474-7979(2009)0000020014.

Henseler, J., Ringle, C., \& Sarstedt, M. (2015). A new criterion for assessing discriminant validity in variance-based structural equation modeling. Journal of the Academy of Marketing Science, 43(1), 11535. https://doi.org/10.1007/s11747-014-0403-8.

Hill, S., Maula, M., Birkinshaw, J., \& Murray, G. (2009). Transferability of the venture capital model to the corporate context: implications for the performance of corporate venture units. Strategic Entrepreneurship Journal, 3(1), 3-27. https://doi.org/10.1002/sej.54.

Hind, C., \& Steyn, R. (2015). Corporate entrepreneurship-distilling the concept. The Southern African Journal of Entrepreneurship and Small Business Management, 7(1), 69-87. https://doi.org/10.4102/sajesbm.v7i1.7.

Ireland, R., Covin, J., \& Kuratko, D. (2009). Conceptualising corporate entrepreneurship strategy. Entrepreneurship Theory and Practice, 33(1), 19-47. https://doi.org/10.1111/j.1540-6520.2008.00279.x. Jager, J., Putnick, D., \& Bornstein, M. (2017). Il. More than just convenient: the scientific merits of homogeneous convenience samples. Monographs of the Society for Research in Child Development, 
82(2), 13-30. https://doi.org/10.1111/mono.12296.

Kantis, H., \& Angelelli, P. (2020). Grandes empresas, startups e innovación en América Latina: Promesas y desafíos. Washington D.C.: BID.

Karacaoglu, K., Bayrakdaroglu, A., \& San, F. (2012). The impact of corporate entrepreneurship on firms' financial performance: evidence from istanbul stock exchange firms. International Business Research, 6(1), 163-175. https://doi.org/10.5539/ibr.v6n1p163.

Kaya, N. (2006). The impact of human resource management practices and corporate entrepreneurship on firm performance: evidence from Turkish firms. The International Journal of Human Resource Management, 17(12), 2074-2090. https://doi.org/10.1080/09585190601000204.

Kelley, D., Singer, S., \& Herrington, M. (2016). GEM 2015-2016 Global Report. Massachusetts, USA: Global Entrepreneurship Monitor (GEM).

Khanna, T., \& Rivkin, J. (2001). Estimating the performance effects of business groups in emerging markets. Strategic Management Journal, 22(1), 45-74. https://doi.org/10.1002/10970266(200101)22:1<45::AID-SMJ147>3.0.CO;2-F.

Kim, H., \& Kim, B. (2016). An entrepreneurial paradox: the moderating effect of the external environment. Asian Journal of Technology Innovation, http://dx.doi.org/10.1080/19761597.2016.1207414.

Knight, G. (1997). Cross-cultural reliability and validity of a scale to measure firm entrepreneurial orientation. Journal of Business Venturing, 12(3), 213-225. https://doi.org/10.1016/S08839026(96)00065-1.

Knox, D. (2019). Why corporate venture capital is more important than ever for the fortune 500. Retrieved from Forbes: https://www.forbes.com/sites/daveknox/2019/11/21/why-corporate-venture-capital-ismore-important-than-ever-for-the-fortune-500/\#718f5f3a41af

Kock, N., \& Hadaya, P. (2018). Minimum sample size estimation in PLS-SEM: The inverse square root and gamma-exponential methods. Information Systems Journal, 28(1), 227-261.

https://doi.org/10.1111/isj.12131.

Kreiser, P., \& Davis, J. (2010). Entrepreneurial orientation and firm performance: the unique impact of innovativeness, proactiveness, and risk-taking. Journal of Small Business \& Entrepreneurship, 23(1), 3951. https://doi.org/10.1080/08276331.2010.10593472.

Kuratko, D. (2017). Corporate entrepreneurship 2.0: research development and future directions. Foundations and Trends $\circledast$ in Entrepreneurship, 13(6), 441-490. https://doi.org/10.1561/0300000082.

Kuratko, D. F., \& Audretsch, D. B. (2013). Clarifying the domains of corporate entrepreneurship. International Entrepreneurship and Management Journal, 9(3), 323-335. https://doi.org/10.1007/s11365- 
Kuratko, D., Hornsby, J., \& Covin, J. (2014). Diagnosing a firm's internal environment for corporate entrepreneurship. Business Horizons, 57(1), 37-47. https://doi.org/10.1016/j.bushor.2013.08.009.

Lee, Y., Zhuang, Y., Joo, M., \& Jun, T. (2019). Revisiting Covin and Slevin (1989): replication and extension of the relationship between entrepreneurial orientation and firm performance. Journal of Business Venturing Insights, 12, e00144. https://doi.org/10.1016/j.jbvi.2019.e00144.

Liu, Y., \& Vrontis, D. (2017). Emerging-market firms venturing into advanced economies: the role of context. Thunderbird International Business Review, 59(3), 255-261. https://doi.org/10.1002/tie.21900.

Lumpkin, G., \& Dess, G. (1996). Clarifying the entrepreneurial orientation construct and linking it to performance. Academy of Management Review, 21(1), 135-172. https://doi.org/10.2307/258632.

Lumpkin, G., \& Dess, G. (2001). Linking two dimensions of entrepreneurial orientation to firm performance: the moderating role of environment and industry life cycle. Journal of Business Venturing, 16(5), 429-451. https://doi.org/10.1016/S0883-9026(00)00048-3.

Marcoulides, G., \& Saunders, C. (2006). Editor's comments: PLS: A Silver Bullet? MIS Quarterly, 30(2), iiiix. https://doi.org/10.2307/25148727.

Miller, A., Wilson, B., \& Adams, M. (1988). Financial performance patterns of new corporate ventures: an alternative to traditional measures. Journal of Business Venturing, 3(4), 287-300.

https://doi.org/10.1016/0883-9026(88)90010-9.

Miller, D. (1983). The correlates of entrepreneurship in three types of firms. Management Science, 29(7), 770-791. https://doi.org/10.1287/mnsc.29.7.770.

Miller, D. (2011). Miller (1983) Revisited: a reflection on EO research and some suggestions for the future. Entrepreneurship Theory and Practice, 35(5), 873-894. https://doi.org/10.1111/j.1540-6520.2011.00457.x.

Miller, D., \& Friesen, P. (1982). Innovation in conservative and entrepreneurial firms: two models of strategic momentum. Strategic Management Journal, 3(1), 1-25.

https://doi.org/10.1002/smj.4250030102.

Mohamad, O., Ramayah, T., Puspowarsito, H., Natalisa, D., \& Saerang, D. (2011). Corporate entrepreneurship and firm performance: the role of business environment as a moderator. IUP Journal of Management Research, 10(3), 7-27.

Morris, M., Kuratko, D., \& Covin, J. (2011). Corporate entrepreneurship and innovation: entrepreneurial development within organizations (3rd ed.). Mason: South-Western Cengage Learning. 
Narayanan, V., Yang, Y., \& Zahra, S. (2009). Corporate venturing and value creation: a review and proposed framework. Research Policy, 38(1), 58-76. https://doi.org/10.1016/j.respol.2008.08.015.

Ortega, L., \& Rotondo, A. (2020). Corporate Venturing Latam Handbook: Guía para la Colaboración entre Corporaciones y Startups. Santiago de Chile: Gobierno de Chile.

Pinchot, G. (1986). Intrapreneuring revisited. European Management Journal, 4(2), 89-94. https://doi.org/10.1016/S0263-2373(86)80016-0.

Prats, J., \& Siota, J. (2018). Open innovation, building, scaling and consolidating your firm's corporate venturing unit. Barcelona: IESE Business School.

Rauch, A., Wiklund, J., Lumpkin, G., \& Frese, M. (2009). Entrepreneurial orientation and business performance: an assessment of past research and suggestions for the future. Entrepreneurship: Theory and Practice, 33(3), 761-787. https://doi.org/10.1111/j.1540-6520.2009.00308.x.

Ringle, C., Sarstedt, M., \& Straub, D. (2012). Editor's comments: a critical look at the use of PLS-SEM in "MIS Quarterly". MIS Quarterly, 36(1), iii-xiv. https://doi.org/10.2307/41410402.

Sakhdari, K., \& Farsi, J. (2016). Business partners and corporate entrepreneurship in developing countries. International Journal of Management and Enterprise Development, 15(1), 61-77. https://doi.org/10.1504/IJMED.2016.075875.

Schaeffer, V. (2015). Corporate entrepreneurship and creativity in large firms: the practice of start-up contests. Journal of Innovation Economics \& Management, 18(3), 25-51. https://doi.org/10.3917/jie.018.0025.

Sharma, P., \& Chrisman, S. (1999). Toward a reconciliation of the definitional issues in the field of corporate entrepreneurship. Entrepreneurship Theory and Practice, 23(3), 11-27.

Siota, J., \& Prats, J. (2020). Corporate venturing latam: corporate giants' collaboration with start-ups in Latin America. Barcelona: IESE Business School.

Stramaglia, A. (2010). On some "dimensions" of the theory of the firm. Rivista Internazionale Di Scienze Sociali, 118(2), 199-223. https://www.jstor.org/stable/41625250.

Tajeddini, K., \& Mueller, S. (2018). Moderating effect of environmental dynamism on the relationship between a firm's entrepreneurial orientation and financial performance. Entrepreneurship Research Journal, 9(4), 1-13. https://doi.org/10.1515/erj-2018-0283.

Tang, J., Tang, Z., Marino, L., Zhang, Y., \& Li, Q. (2008). Exploring an inverted U-shape relationship between entrepreneurial orientation and performance in Chinese ventures. Entrepreneurship Theory and Practice, 32(1), 219-239. 
Thomas, A., \& Mueller, S. (2000). A case for comparative entrepreneurship: assessing the relevance of culture. Journal of International Business Studies, 31(2), 287-301. https://www.jstor.org/stable/155638.

Tosi, H., Aldag, R., \& Storey, R. (1973). On the measurement of the environment: an assesment of the Lawrence and Lorsch enviromental uncertainty subscale. Administrative Science Quarterly, 18(1), 27-36. https://doi.org/10.2307/2391925.

Vozikis, G., Bruton, G., Prasad, D., \& Merikas, A. (1999). Linking corporate entrepreneurship to financial theory through additional value creation. Entrepreneurship Theory and Practice, 24(2), 33-43. https://doi.org/10.1177/104225879902400204.

Wiklund, J. (1999). The sustainability of the entrepreneurial orientation. Performance Relationship. Entrepreneurship Theory and Practice, 24(1), 37-48. https://doi.org/10.1177/104225879902400103.

Wiklund, J., \& Shepherd, D. (2003). Knowledge-based resources, entrepreneurial orientation, and the performance of small and medium-sized businesses. Strategic Management Journal, 24(13), 1307-1314. https://doi.org/10.1002/smj.360.

Wiklund, J., \& Shepherd, D. (2005). Entrepreneurial orientation and small business performance: a configurational approach. Journal of Business Venturing, 20(1), 71-91. https://doi.org/10.1016/j.jbusvent.2004.01.001.

Wilches, G., \& Rodríguez, C. (2016). El proceso evolutivo de los conglomerados o grupos económicos en Colombia. Revista Innovar Journal Revista de Ciencias Administrativas y Sociales, 26(60), 11-34. http://dx.doi.org/10.15446/innovar.v26n60.55478.

Yiu, D., Lu, Y., Bruton, G., \& Hoskisson, R. (2007). Business groups: an integrated model to focus future research. Journal of Management Studies, 44(8), 1551-1579. https://doi.org/10.1111/j.14676486.2007.00735.x.

Zahra, S. (1993). Environment, corporate entrepreneurship and financial performance: a taxonomic approach. Journal of Business Venturing, 8(4), 319-340. https://doi.org/10.1016/0883-9026(93)90003-N.

Zahra, S. (1996). Governance, ownership and corporate entrepreneurship: the moderating impact of industry technological opportunities. The Academy of Management Journal, 39(6), 1713-1735. https://doi.org/10.5465/257076.

Zahra, S. A. (1995). Environment, corporate entrepreneurship and financial performance: the case of management leveraged buyouts. Journal of Business Venturing, 10(3), 225-247. https://doi.org/10.1016/0883-9026(94)00024-0.

Zahra, S., \& Covin, J. (1995). Contextual influences on the corporate entrepreneurship-performance relationship: a longitudinal analysis. Journal of Business Venturing, 10(1), 43-58. https://doi.org/10.1016/0883-9026(94)00004-E. 
Zhang, H. (2009). Conception design and empirical research of multinational subsidiary's entrepreneurial orientation. IEEM - IEEE Int. Conf. Ind. Eng. Eng. Manage., 1214-1218. Scopus.

https://doi.org/10.1109/IEEM.2009.5372991

Zhou, K. Z., Gao, G., \& Zhao, H. (2017). State ownership and firm innovation in China: an integrated view of institutional and efficiency logics. Administrative Science Quarterly, 62(2), 375-404.

https://doi.org/10.1177/0001839216674457.

\section{Figures}

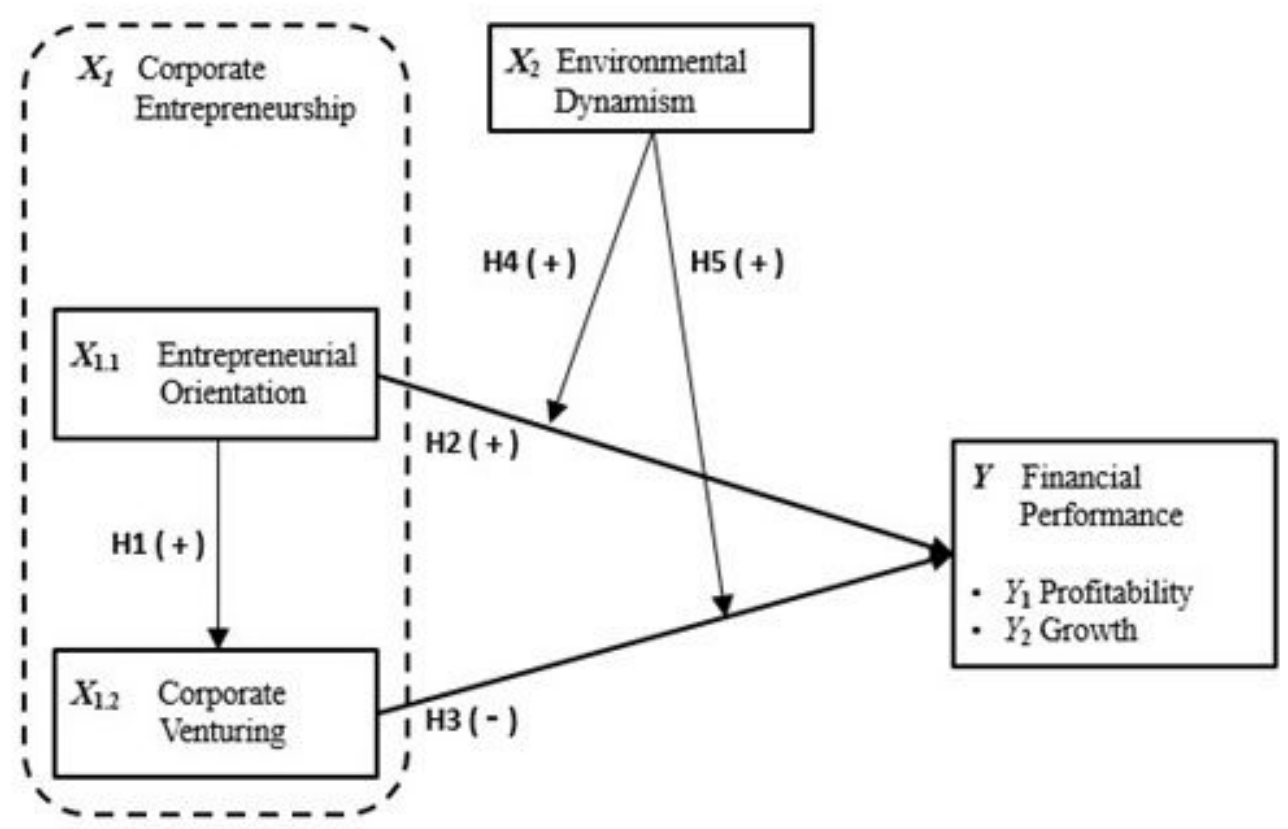

\section{Figure 1}

Hypothesized model 


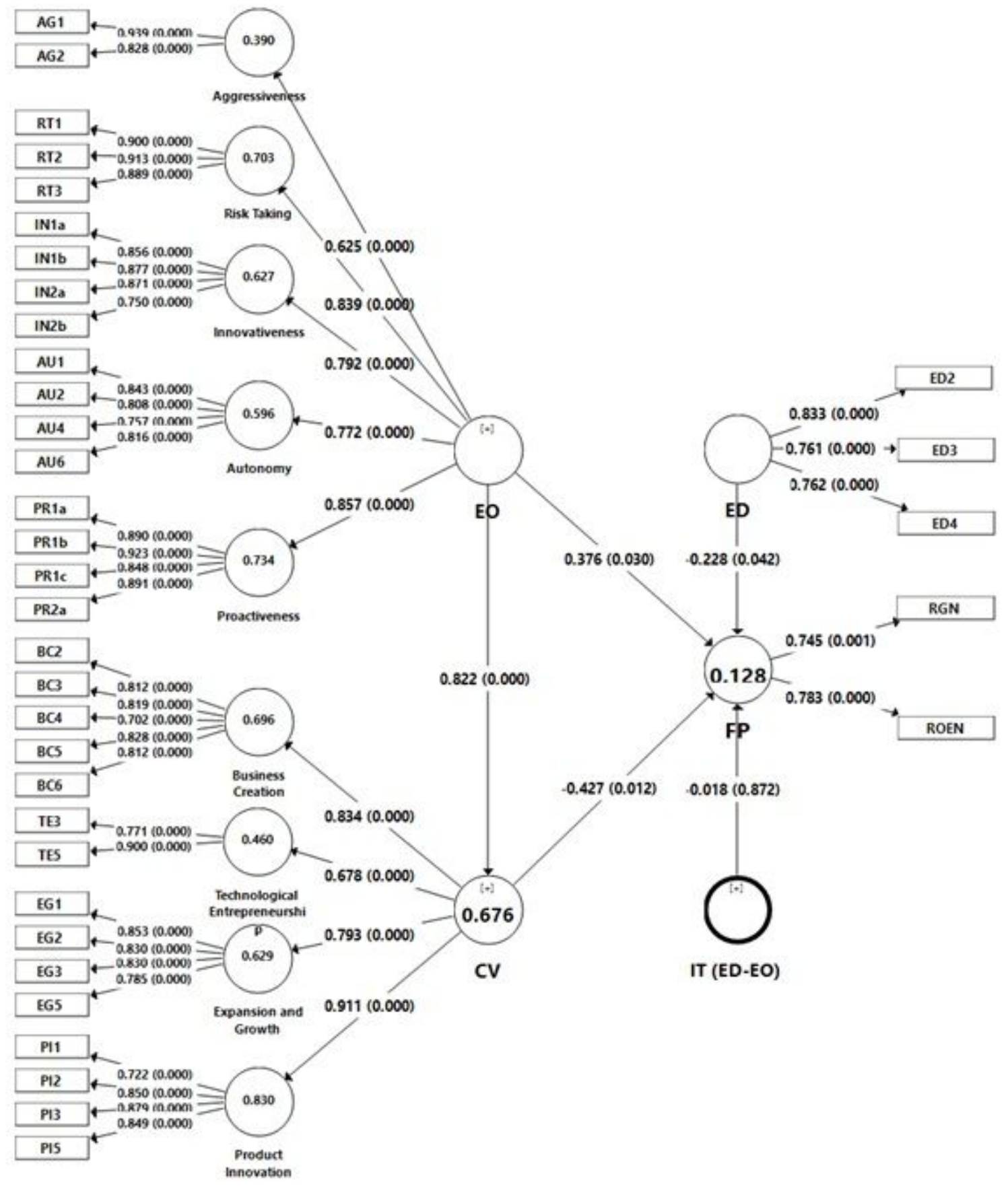

Figure 2

Results of the SEM moderating effect of ED on EO and FP Note. The names of the items correspond to the way they are labeled on their measurement scales. 


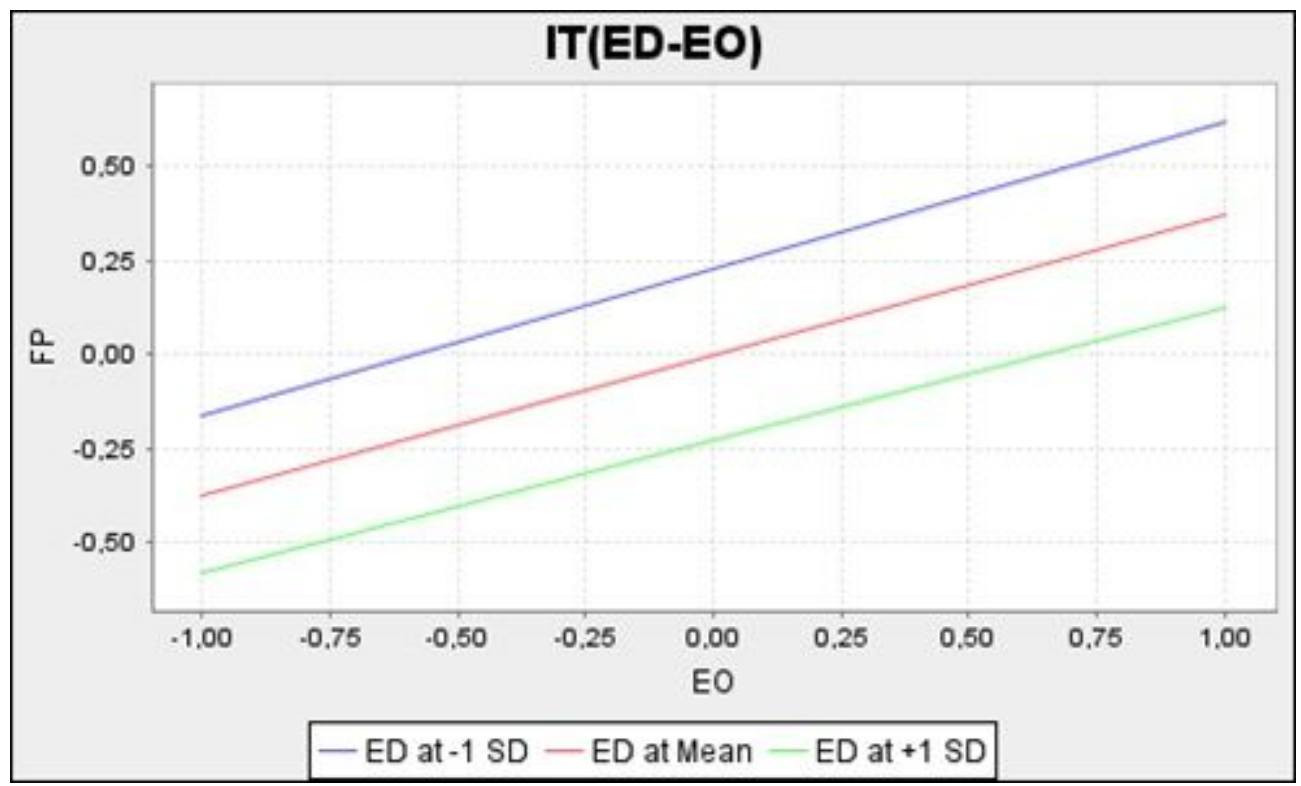

\section{Figure 3}

Moderating effect of ED on EO and FP relationship Note. Financial performance (FP); standard deviation (SD); interaction term (IT).

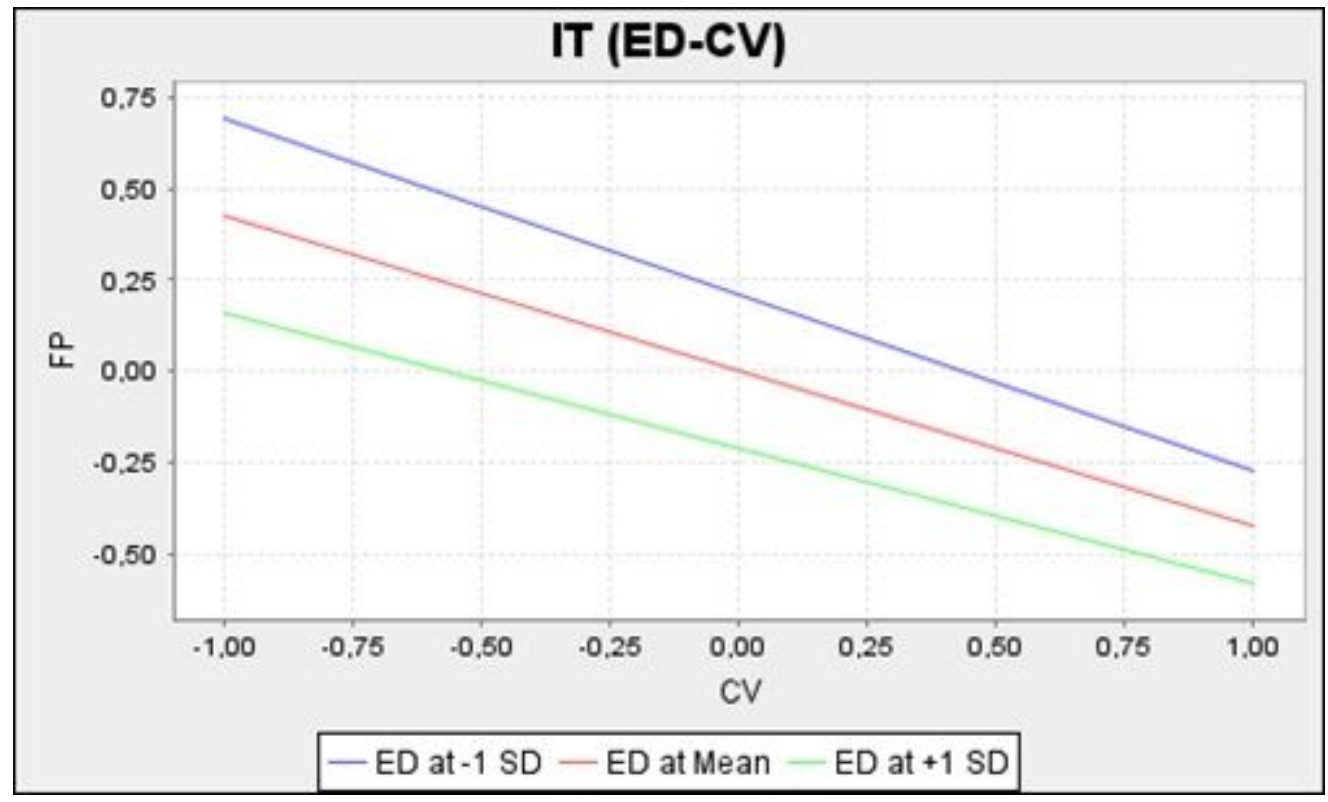

\section{Figure 4}

Moderating effect of ED on CV and FP relationship Note. Financial performance (FP); standard deviation (SD); interaction term (IT). 


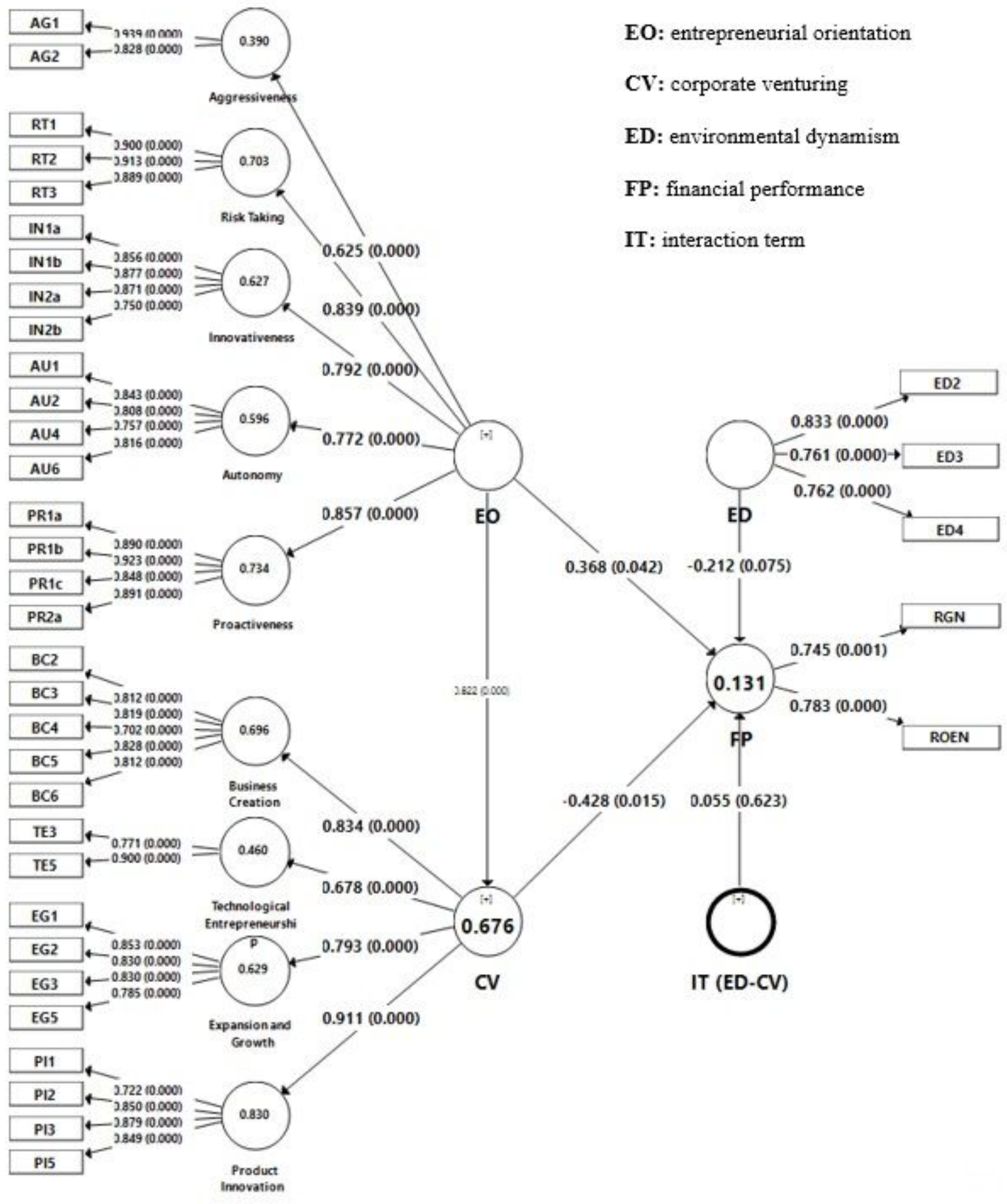

Figure 5

Results of the SEM moderating effect of ED on CV and FP

\section{Supplementary Files}

This is a list of supplementary files associated with this preprint. Click to download.

- Appendix.docx 
- 4DatasetCorporateEntrepreneurshipRevised.xIsx 